\title{
OPEN Metamorphosis-related changes in the free fatty acid profiles of Sarcophaga (Liopygia) argyrostoma (Robineau-Desvoidy, 1830)
}

\author{
Agata Kaczmarek ${ }^{1 凶}$, Anna Katarzyna Wrońska ${ }^{1}$, Michalina Kazek $^{1}$ \& \\ Mieczysława Irena Boguś s, $^{2}$
}

The flies of the Sarcophagidae, widespread throughout the temperate zone, are of great significance in Medicine, Veterinary science, Forensics and Entomotoxicology. Lipids are important elements of cell and organelle membranes and a source of energy for embryogenesis, metamorphosis and flight. Cuticular lipids protect from desiccation and act as recognition cues for species, nest mates and castes, and are a source of various pheromones. The free fatty acid (FFA) profile of cuticular and internal extracts of Sarcophaga (Liopygia) argyrostoma (Robineau-Desvoidy, 1830) larvae, pupae and adults was determined by gas chromatography-mass spectrometry (GC-MS). The larvae, pupae and adults contained FFAs from $\mathrm{C} 5: 0$ to $\mathrm{C28}: 0$. The extracts differed quantitatively and qualitatively from each other: $\mathrm{C} 18: 1>\mathrm{C} 16: 1>\mathrm{C} 16: 0>\mathrm{C} 18: 0$ predominated in the cuticular and internal extracts from the larvae and adults, while 18:1 $>\mathrm{C} 16: 0>\mathrm{C} 16: 1>\mathrm{C} 18: 0$ predominated in the pupae. The FFA profile of the cuticle varies considerably between each development stage: $\mathrm{C} 23: 0$ and C25:0 are only present in larvae, $\mathrm{C} 28: 0$ in the pupal cuticle, and $\mathrm{C} 12: 1$ and $\mathrm{C} 18: 3$ in internal extracts from adults. The mechanisms underlying this diversity are discussed herein.

The Sarcophagidae is a large family represented by more than 3000 species $^{1}$ and its subfamily Sarcophaginae has the highest diversity of species in Central Europe ${ }^{2}$. Its members present a variety of feeding habits, including sarcophagy, necrophagy and/or coprophagy, especially in the larval stage, and therefore play an important role in matter decomposition ${ }^{3-5}$. Sarcophaga flies are natural hosts of the parasitic wasp Nasonia vitripennis and are often used in laboratory studies for wasp culture ${ }^{6-8}$. They also have medical and veterinary significance as obligatory and facultative parasitoids, predators, and myiasis-causing factors ${ }^{9-16}$. Several species are synanthropic and may be responsible for the mechanical transmission of pathogens to food and humans, with potential consequences for public health ${ }^{12,17,18}$. They are suitable animals for studying the physiology and biochemistry of insects, particularly their endocrinology ${ }^{19,20}$, diapause ${ }^{21-23}$, reproduction ${ }^{24}$ and immunity ${ }^{25-27}$. In addition, they are regarded as having high forensic value, due to their ovoviviparity (or ovolarviparity): they deposit maggots instead of eggs directly on a corpse, and due to the larger size of the larvae and their higher efficiency of sarcophagid flies, they act as convenient markers of decay ${ }^{28-31}$. Additionally, drugs or other toxic substances that could be undetected in decomposed tissues can be detected in the tissues of the larvae found in the corpse (entomotoxicology) ${ }^{28,32}$. However, their use in criminal investigations is still limited due to difficulties in species identification. Such difficulties are present for almost all life stages, especially the larval stages, which demonstrate little morphological diversity; there is also a need to better understand the ecology, behaviour and distribution of the insects, and to improve sample collection, as the larvae can spread for up to $10 \mathrm{~m}$ from the cadaver ${ }^{31,33-36}$.

Due to their high medical, veterinary and forensic importance, there is a great need to better understand the morphological and physiological processes of Sarcophaga flies. The present study examines the changes in lipid profile during three development stages of Sarcophaga (Liopygia) argyrostoma (Robineau-Desvoidy, 1830). It has often been recorded that FFA profiles differ considerably between development stages, even within a single species $^{37-44}$. 


\begin{tabular}{|c|c|c|c|c|c|c|c|c|}
\hline \multirow[b]{3}{*}{ Extracts made from } & \multirow[b]{3}{*}{$\mathbf{N}$} & \multirow[b]{3}{*}{ Insects mass (g) } & \multicolumn{6}{|c|}{ Extract mass } \\
\hline & & & \multicolumn{3}{|l|}{ (mg) } & \multicolumn{3}{|c|}{ (mg/insect) } \\
\hline & & & I & II & III & I & II & III \\
\hline Larvae & 12 & 1.039 & 0.001 & 0.001 & 0.900 & 0.0001 & 0.0001 & 0.075 \\
\hline Pupae & 20 & 0.972 & 0.600 & 0.930 & 0.520 & 0.030 & 0.047 & 0.026 \\
\hline Adults & 12 & 1.071 & 2.060 & 3.570 & 7.660 & 0.172 & 0.298 & 0.638 \\
\hline
\end{tabular}

Table 1. The numbers of Sarcophaga argyrostoma used and masses of extracts obtained. $N$ total number of individuals, I petroleum ether extract, II dichloromethane extract, III dichloromethane extract after sonication.

Lipids are important components of cells and play a key role in the well-being of insects. Internal free fatty acids (FFAs) are essential parts of cell and organelle membranes, serve as important sources of energy, and act as precursors for secondary metabolites, waxes, pheromones and defensive secretions $s^{45-47}$.

Cuticular lipids are a diverse group of compounds, whose content and composition in the insect vary according to diet and climate. Cuticular lipids (including FFAs) perform many important functions associated with maintaining homeostasis within the insect. Most importantly, their presence minimizes transpiration and protects terrestrial insects from desiccation ${ }^{48,49}$. Cuticular lipids also play roles in several biochemical, physiological, and semiochemical (behaviour and signalling) processes. They act as recognition cues for species, nest mate and caste; they also serve as a reservoir for a suite of pheromones responsible for sexual attraction, epideictic activity (insect display behaviour), territorial markers, alarm, chemical defence, and thermoregulation, predator-prey and parasitoid-host interactions, and mimicry and camouflage $\mathrm{e}^{50-53}$. The lipid profile of the insect cuticle is also a crucial indicator of susceptibility or resistance to fungal invasion ${ }^{41,54,55}$, and hence an understanding of its FFA profile could play a significant role in the identification of flies and the control of their populations. In addition, changes in the lipid composition related to the individual stages of development of holometabolous insects are also associated with differences in such aspects as body composition, lifestyle, diet and environment.

Hence, there is a great need for further research on the FFA profiles for insects. Therefore, the aim of this study was to describe metamorphosis-related changes in FFA profiles in the flesh fly S. argyrostoma.

\section{Results}

The present work characterises the chemical composition of cuticular and internal FFAs of S. argyrostoma. Three types of extraction were performed for the larval, pupal and adult material. The cuticular lipids were found in the petroleum ether (extract I) and dichloromethane (extract II) extracts, and the internal lipids in extract III. The total masses of the extracts are shown in Table 1. Cuticular extracts of larvae amounted to $0.002 \mathrm{mg}$ in the cuticular extracts $(0.00017 \mathrm{mg}$ per larva) and $0.900 \mathrm{mg}$ in the internal extracts $(0.075 \mathrm{mg}$ per larva). Greater quantities of cuticular extracts were obtained from pupae $1.530 \mathrm{mg}(0.077 \mathrm{mg}$ per pupa) than larvae; however, lower quantities of internal extracts were obtained from pupae $(0.520 \mathrm{mg} ; 0.026 \mathrm{mg}$ per individual). The most efficient extraction was observed for adults: the cuticular extract yielded $5.630 \mathrm{mg}(0.469 \mathrm{mg}$ per insect), and the internal extract yielded $7.660 \mathrm{mg}(0.638 \mathrm{mg}$ per insect). The masses of the extracts are shown in Table 1.

These extracts were further analysed by GC-MS. A comparison of the FFA profiles of the cuticle surface (sum of extracts I and II) and the internal structures of the insect is given in Table 2; the raw data is appended in Table S1. The highest total FFA content was observed in adults, in both the cuticular $(1865.278 \pm 19.580 \mu \mathrm{g} / \mathrm{g}$ of insect body) and internal extracts $(3811.660 \pm 9.217 \mu \mathrm{g} / \mathrm{g}$ of insect body), while the lowest was observed for pupae: $70.821 \pm 2.381 \mu \mathrm{g} / \mathrm{g}$ insect body mass in the cuticular extract, and $63.654 \pm 1.167 \mu \mathrm{g} / \mathrm{g}$ insect body mass in the internal extract. In larvae, the total FFA content equalled $186.576 \pm 7.550 \mu \mathrm{g} / \mathrm{g}$ insect body mass in the cuticular extracts, and $190.665 \pm 8.849 \mu \mathrm{g} / \mathrm{g}$ insect body mass in the internal extract. Only the extracts from the adults demonstrated a statistically significant difference in total FFA content between cuticular and internal fractions $(\mathrm{p}<0.001)$.

The individual FFAs present in each extract were identified and quantified. Example mass spectra of the trimethylsilyl (TMS) esters of octadecatrienoic acid (C18:3), octadecadienoic acid (C18:2), octadecenoic acid (C18:1) and octadecanoic acid (C18:0) are shown in Fig. 1.

The extracts from S. argyrostoma larvae were found to contain 33 FFAs (Table 2). The cuticular extracts contained 31 FFAs from C5:0 to C26:0: 21 saturated (C5:0-C20:0, C22:0-C26:0) and 11 unsaturated (C14:1, C15:1, C16:1, C17:1, C18:2, C18:1, C19:1, C20:5, C20:4, C20:3 and C20:1).

The internal lipids had a similar fatty acid profile, with the exception that $\mathrm{C} 5: 0$ was absent. Most FFAs were present at similar levels; however, C9:0, C17:0, C18:0, C22:0, C23:0, C24:0, C25:0 and C26:0 were significantly higher in the cuticle extract. The two extracts were found to have similar total amounts of FFAs. The total ion current (TIC) chromatogram of fatty acids (TMS esters) of the ether extract (Extract I) from the larvae is given in Fig. 2.

The cuticular extracts from pupae contained 26 cuticular FFAs from C5:0 to C28:0: 18 saturated (C5:0-C10:0, C12:0-C18:0, C20:0, C22:0, C24:0, C26:0 and C28:0) and eight unsaturated (C14:1, C15:1, C16:1, C17:1, C18:2, C18:1, C20:3 and C20:1). The internal extract contained 23 FFAs. A comparison found the internal fractions to contain FFAs C20:4 and C20:5, absent in the cuticular fractions, but to lack C13:0, C20:3, C20:1, C26:0 and C28:0, present in the cuticular fractions. Most FFAs were found in similar concentrations in the cuticle and the internal extracts, except for C9:0, C12:0, C14:0, C18:0 and C22:0, which were significantly higher in the cuticle. The two extracts from the pupae also demonstrated similar total FFA levels to each other; however, these values 


\begin{tabular}{|c|c|c|c|c|c|c|}
\hline \multirow[b]{2}{*}{ FFA } & \multicolumn{2}{|l|}{ Larvae } & \multicolumn{2}{|l|}{ Pupae } & \multicolumn{2}{|l|}{ Adults } \\
\hline & \begin{tabular}{|l|} 
Cuticular \\
\end{tabular} & Internal & Cuticular & Internal & Cuticular & Internal \\
\hline C5:0 & $0.147 \pm 0.008^{\mathrm{A}-\mathrm{C}}$ & $\mathrm{ND}^{\mathrm{A}}$ & $0.021 \pm 0.004^{\mathrm{B}}$ & $0.013 \pm 0.005^{\mathrm{C}}$ & $0.732 \pm 0.019^{A-C}$ & $0.212 \pm 0.026^{\mathrm{A}-\mathrm{C}}$ \\
\hline C6:0 & $0.234 \pm 0.001^{\mathrm{A}}$ & $0.349 \pm 0.053^{\mathrm{B}}$ & $0.470 \pm 0.016^{\mathrm{C}}$ & $0.224 \pm 0.018^{\mathrm{D}}$ & $1.785 \pm 0.155^{\mathrm{A}-\mathrm{D}}$ & $1.147 \pm 0.096^{\mathrm{A}-\mathrm{D}}$ \\
\hline C7:0 & $0.056 \pm 0.000^{\mathrm{A}}$ & $0.057 \pm 0.003^{\mathrm{B}}$ & $0.031 \pm 0.001^{\mathrm{C}}$ & $0.034 \pm 0.002^{\mathrm{D}}$ & $0.636 \pm 0.131^{A-D}$ & $0.308 \pm 0.020^{A-D}$ \\
\hline C8:0 & $0.400 \pm 0.007^{\mathrm{A}}$ & $0.143 \pm 0.007^{\mathrm{B}}$ & $0.195 \pm 0.032^{\mathrm{C}}$ & $0.059 \pm 0.006^{\mathrm{D}}$ & $1.091 \pm 0.288^{\mathrm{A}-\mathrm{E}}$ & $0.386 \pm 0.052^{\mathrm{E}}$ \\
\hline C9:0 & $0.824 \pm 0.000^{\mathrm{AB}}$ & $0.451 \pm 0.010^{\mathrm{A}}$ & $0.351 \pm 0.018^{\mathrm{B}}$ & $0.183 \pm 0.014^{\mathrm{AB}}$ & $1.951 \pm 0.073^{\mathrm{AB}}$ & $1.146 \pm 0.076^{\mathrm{AB}}$ \\
\hline C10:0 & $0.108 \pm 0.003^{\mathrm{A}}$ & $0.048 \pm 0.002^{\mathrm{B}}$ & $0.063 \pm 0.003^{\mathrm{C}}$ & $0.027 \pm 0.005^{\mathrm{D}}$ & $0.372 \pm 0.042^{A-D}$ & $0.270 \pm 0.045^{\mathrm{A}-\mathrm{D}}$ \\
\hline C11:0 & $0.043 \pm 0.001^{\mathrm{A}}$ & $0.036 \pm 0.002^{\mathrm{B}}$ & $\mathrm{ND}^{\mathrm{C}}$ & $\mathrm{ND}^{\mathrm{D}}$ & $2.512 \pm 0.120^{A-D}$ & $3.122 \pm 0.151^{\mathrm{A}-\mathrm{D}}$ \\
\hline C12:1 & $\mathrm{ND}^{A}$ & $\mathrm{ND}^{\mathrm{B}}$ & $\mathrm{ND}^{\mathrm{C}}$ & $\mathrm{ND}^{\mathrm{D}}$ & $\mathrm{ND}^{\mathrm{E}}$ & $0.917 \pm 0.049^{A-E}$ \\
\hline C12:0 & $0.493 \pm 0.007^{\mathrm{A}}$ & $0.357 \pm 0.011^{\mathrm{B}}$ & $0.216 \pm 0.011^{\mathrm{A}}$ & $0.094 \pm 0.010^{\mathrm{AB}}$ & $3.122 \pm 0.149^{\mathrm{AB}}$ & $2.791 \pm 0.114^{\mathrm{AB}}$ \\
\hline C13:0 & $0.049 \pm 0.001^{\mathrm{A}}$ & $0.020 \pm 0.004^{\mathrm{B}}$ & $0.027 \pm 0.013^{\mathrm{C}}$ & $\mathrm{ND}^{\mathrm{D}}$ & $0.225 \pm 0.018^{\mathrm{A}-\mathrm{D}}$ & $0.269 \pm 0.044^{\mathrm{A}-\mathrm{D}}$ \\
\hline C14:1 & $1.682 \pm 0.033^{\mathrm{A}}$ & $1.947 \pm 0.063^{\mathrm{B}}$ & $0.106 \pm 0.016^{\mathrm{A}}$ & $0.104 \pm 0.014^{\mathrm{B}}$ & $14.969 \pm 0.522^{\mathrm{AB}}$ & $21.864 \pm 0.906^{\mathrm{AB}}$ \\
\hline C14:0 & $3.843 \pm 0.016^{\mathrm{A}}$ & $4.257 \pm 0.075^{\mathrm{B}}$ & $1.498 \pm 0.068^{\mathrm{B}}$ & $0.754 \pm 0.012^{\mathrm{B}}$ & $25.098 \pm 0.555^{\mathrm{AB}}$ & $41.213 \pm 1.096^{\mathrm{AB}}$ \\
\hline C15:1 & $0.275 \pm 0.012^{\mathrm{A}}$ & $0.291 \pm 0.032^{\mathrm{B}}$ & $0.039 \pm 0.007^{\mathrm{A}}$ & $0.017 \pm 0.005^{\mathrm{B}}$ & $2.408 \pm 0.055^{\mathrm{AB}}$ & $4.091 \pm 0.081^{\mathrm{AB}}$ \\
\hline C15:0 & $0.533 \pm 0.011^{\mathrm{A}}$ & $0.473 \pm 0.012^{\mathrm{B}}$ & $0.299 \pm 0.017^{\mathrm{C}}$ & $0.193 \pm 0.0013^{\mathrm{D}}$ & $5.429 \pm 0.151^{A-D}$ & $9.938 \pm 0.287^{\mathrm{A}-\mathrm{D}}$ \\
\hline C16:1 & $41.580 \pm 1.484^{\mathrm{A}}$ & $55.917 \pm 3.394^{\mathrm{B}}$ & $8.454 \pm 0.480^{\mathrm{A}}$ & $9.884 \pm 0.169^{\mathrm{B}}$ & $476.463 \pm 17.290^{\mathrm{AB}}$ & $916.970 \pm 4.513^{\mathrm{AB}}$ \\
\hline C16:0 & $33.788 \pm 0.019^{\mathrm{A}}$ & $33.230 \pm 0.473^{\mathrm{B}}$ & $15.492 \pm 0.528^{\mathrm{A}}$ & $11.698 \pm 0.173^{\mathrm{B}}$ & $311.453 \pm 0.891^{\mathrm{AB}}$ & $640.327 \pm 5.246^{\mathrm{AB}}$ \\
\hline C17:1 & $1.242 \pm 0.218^{\mathrm{A}}$ & $1.938 \pm 0.004^{\mathrm{B}}$ & $0.362 \pm 0.022^{\mathrm{C}}$ & $0.258 \pm 0.005^{\mathrm{D}}$ & $26.128 \pm 0.321^{\mathrm{A}-\mathrm{D}}$ & $48.126 \pm 4.842^{A-D}$ \\
\hline C17:0 & $0.810 \pm 0.008^{\mathrm{A}-\mathrm{C}}$ & $0.425 \pm 0.008^{\mathrm{A}}$ & $0.454 \pm 0.025^{\mathrm{B}}$ & $0.269 \pm 0.035^{\mathrm{C}}$ & $5.915 \pm 0.137^{\mathrm{A}-\mathrm{C}}$ & $11.704 \pm 0.090^{\mathrm{A}-\mathrm{C}}$ \\
\hline C18:3 & $\mathrm{ND}^{A}$ & $\mathrm{ND}^{\mathrm{B}}$ & $\mathrm{ND}^{\mathrm{C}}$ & $\mathrm{ND}^{\mathrm{D}}$ & $\mathrm{ND}^{\mathrm{E}}$ & $14.205 \pm 0.476^{\mathrm{A}-\mathrm{E}}$ \\
\hline C18:2 & $1.901 \pm 0.132^{\mathrm{A}}$ & $1.519 \pm 0.194^{\mathrm{B}}$ & $1.005 \pm 0.018^{\mathrm{C}}$ & $2.957 \pm 0.299^{\mathrm{D}}$ & $12.575 \pm 0.172^{A-D}$ & $25.414 \pm 2.157^{\mathrm{A}-\mathrm{D}}$ \\
\hline C18:1 & $77.238 \pm 5.622^{\mathrm{A}}$ & $77.397 \pm 10.728^{\mathrm{B}}$ & $31.081 \pm 0.969^{\mathrm{C}}$ & $30.459 \pm 0.279^{\mathrm{D}}$ & $891.201 \pm 35.577^{\mathrm{A}-\mathrm{D}}$ & $1872.927 \pm 8.787^{\mathrm{A}-\mathrm{D}}$ \\
\hline C18:0 & $12.296 \pm 0.109^{\mathrm{AB}}$ & $6.203 \pm 0.081^{\mathrm{A}}$ & $6.188 \pm 0.184^{\mathrm{B}}$ & $2.987 \pm 0.071^{\mathrm{AB}}$ & $32.122 \pm 1.073^{\mathrm{AB}}$ & $67.515 \pm 1.235^{\mathrm{AB}}$ \\
\hline C19:1 & $0.215 \pm 0.012^{\mathrm{AB}}$ & $0.119 \pm 0.005^{\mathrm{C}}$ & $\mathrm{ND}^{A C}$ & $\mathrm{ND}^{\mathrm{BC}}$ & $1.647 \pm 0.045^{\mathrm{AC}}$ & $3.771 \pm 0.055^{\mathrm{AC}}$ \\
\hline C19:0 & $0.155 \pm 0.004^{\mathrm{A}}$ & $0.063 \pm 0.003^{\mathrm{B}}$ & $\mathrm{ND}^{\mathrm{C}}$ & $\mathrm{ND}^{\mathrm{D}}$ & $0.266 \pm 0.056^{\mathrm{CD}}$ & $0.731 \pm 0.143^{\mathrm{A}-\mathrm{D}}$ \\
\hline C20:5 & $0.512 \pm 0.006^{\mathrm{A}}$ & $0.746 \pm 0.010^{\mathrm{B}}$ & $\mathrm{ND}^{\mathrm{C}}$ & $0.744 \pm 0.034^{\mathrm{D}}$ & $17.893 \pm 0.345^{\mathrm{A}-\mathrm{D}}$ & $60.680 \pm 0.503^{A-D}$ \\
\hline C20:4 & $1.427 \pm 0.016^{\mathrm{A}}$ & $1.981 \pm 0.005^{\mathrm{C}}$ & $\mathrm{ND}^{\mathrm{C}}$ & $1.237 \pm 0.048^{\mathrm{C}}$ & $14.131 \pm 0.070^{\mathrm{A}-\mathrm{C}}$ & $42.805 \pm 0.567^{\mathrm{A}-\mathrm{C}}$ \\
\hline C20:3 & $0.231 \pm 0.022^{\mathrm{A}}$ & $0.255 \pm 0.019^{\mathrm{B}}$ & $0.228 \pm 0.017^{\mathrm{C}}$ & $\mathrm{ND}^{\mathrm{D}}$ & $2.370 \pm 0.749^{A-D}$ & $3.802 \pm 0.036^{\mathrm{A}-\mathrm{D}}$ \\
\hline C20:1 & $0.923 \pm 0.057^{\mathrm{A}}$ & $0.296 \pm 0.017^{\mathrm{B}}$ & $0.349 \pm 0.022^{\mathrm{C}}$ & $\mathrm{ND}^{\mathrm{D}}$ & $2.091 \pm 0.287^{\mathrm{A}-\mathrm{D}}$ & $4.262 \pm 0.730^{A-D}$ \\
\hline C20:0 & $0.488 \pm 0.005^{\mathrm{A}}$ & $0.278 \pm 0.020^{\mathrm{B}}$ & $0.700 \pm 0.012^{\mathrm{C}}$ & $0.277 \pm 0.028^{\mathrm{D}}$ & $2.569 \pm 0.423^{\mathrm{A}-\mathrm{D}}$ & $4.995 \pm 0.523^{\mathrm{A}-\mathrm{D}}$ \\
\hline C22:0 & $1.348 \pm 0.014^{\mathrm{ABD}}$ & $0.492 \pm 0.005^{\mathrm{ACD}}$ & $1.138 \pm 0.012^{\mathrm{CF}}$ & $0.548 \pm 0.053^{\mathrm{BF}}$ & $2.541 \pm 0.236^{\mathrm{AF}}$ & $2.443 \pm 0.058^{\mathrm{DF}}$ \\
\hline C23:0 & $0.270 \pm 0.001^{\mathrm{A}-\mathrm{D}}$ & $0.160 \pm 0.026^{\mathrm{A}-\mathrm{D}}$ & $\mathrm{ND}^{\mathrm{A}}$ & $\mathrm{ND}^{\mathrm{B}}$ & $\mathrm{ND}^{\mathrm{C}}$ & $\mathrm{ND}^{\mathrm{D}}$ \\
\hline C24:0 & $1.910 \pm 0.061^{\mathrm{A}-\mathrm{D}}$ & $0.684 \pm 0.007^{\mathrm{AD}}$ & $1.178 \pm 0.044^{\mathrm{BF}}$ & $0.633 \pm 0.058^{\mathrm{CE}}$ & $3.202 \pm 0.105^{\mathrm{A}-\mathrm{C}}$ & $3.312 \pm 0.433^{\mathrm{D}-\mathrm{F}}$ \\
\hline C25:0 & $0.214 \pm 0.008^{\mathrm{A}-\mathrm{D}}$ & $0.045 \pm 0.004^{\mathrm{A}-\mathrm{D}}$ & $\mathrm{ND}^{\mathrm{A}}$ & $\mathrm{ND}^{\mathrm{B}}$ & $\mathrm{ND}^{\mathrm{C}}$ & $\mathrm{ND}^{\mathrm{D}}$ \\
\hline C26:0 & $1.342 \pm 0.016^{\mathrm{AB}}$ & $0.489 \pm 0.007^{\mathrm{AB}}$ & $0.877 \pm 0.027^{\mathrm{AB}}$ & $\mathrm{ND}^{\mathrm{A}}$ & $2.385 \pm 0.198^{\mathrm{AB}}$ & $\mathrm{ND}^{\mathrm{B}}$ \\
\hline C28:0 & $\mathrm{ND}^{\mathrm{A}}$ & $\mathrm{ND}^{\mathrm{B}}$ & $0.747 \pm 0.100^{\mathrm{A}-\mathrm{E}}$ & $\mathrm{ND}^{\mathrm{C}}$ & $\mathrm{ND}^{\mathrm{D}}$ & $\mathrm{ND}^{\mathrm{E}}$ \\
\hline Sum of FFA & $186.576 \pm 7.550^{\mathrm{AB}}$ & $190.665 \pm 8.849^{\mathrm{CD}}$ & $70.821 \pm 2.381^{\mathrm{AC}}$ & $63.654 \pm 1.167^{\mathrm{BD}}$ & $1865.278 \pm 19.580^{\mathrm{A}-\mathrm{D}}$ & $3811.660 \pm 9.217^{\mathrm{A}-\mathrm{D}}$ \\
\hline
\end{tabular}

Table 2. Fatty acid contents in the cuticular and internal lipids extracted from Sarcophaga argyrostoma $[\mu \mathrm{g} / \mathrm{g}$ of body mass $\pm \mathrm{SD}$ ]. FFA free fatty acids, $S D$ standard deviation, $N D$ not detected; statistically significant differences are marked with the same letters (ANOVA, Test HSD Tukey, $\mathrm{p}<0.05$ ), see Table S1 for raw data.

were 2.6-times lower (cuticle) and three-times lower (internal) than the analogous extracts from the larvae. The TIC chromatogram of the TMS esters of the dichloromethane extract (Extract II) from S. argyrostoma pupae is given in Fig. 3.

Among the adults, the cuticular extracts contained 30 FFAs from C5:0 to C26:0: 19 saturated (C5:0-C20:0, C22:0, C24:0 and C26:0) and 11 unsaturated (C14:1, C15:1, C16:1, C17:1, C18:2, C18:1, C19:1, C20:5, C20:4, C20:3 and C20:1). A similar FFA profile was observed in the internal extracts; however, C26:0 was absent in extract III, and C12:1 and C18:3 were present, both of which were missing from the cuticular extracts. A higher concentration of short-chain FFAs was observed in the cuticular fraction, while the long-chain FFAs predominated in the internal fraction. However, the internal extracts demonstrated twice the total FFA content than the cuticular extracts $(\mathrm{p}<0.001)$. The TIC chromatograms of TMS esters of the dichloromethane extract (Extract III) from the adults are given in Fig. 4.

The predominant FFA in all developmental stages was C18:1 $(77 \mu \mathrm{g} / \mathrm{g}$ insect body mass in larvae, $30-31 \mu \mathrm{g} / \mathrm{g}$ insect body mass in pupae, and $891-1873 \mu \mathrm{g} / \mathrm{g}$ insect body mass in adults, respectively). High concentrations of C16:1 was measured only in larvae $(42-56 \mu \mathrm{g} / \mathrm{g}$ of insect body) and adults (476-917 $\mu \mathrm{g} / \mathrm{g}$ of insect body). The third most dominant acid was C16:0 (33-34 $\mu \mathrm{g} / \mathrm{g}$ insect body mass in larvae, $12-15 \mu \mathrm{g} / \mathrm{g}$ insect body mass in pupae, and 311-640 $\mu \mathrm{g} / \mathrm{g}$ insect body mass in adults). 

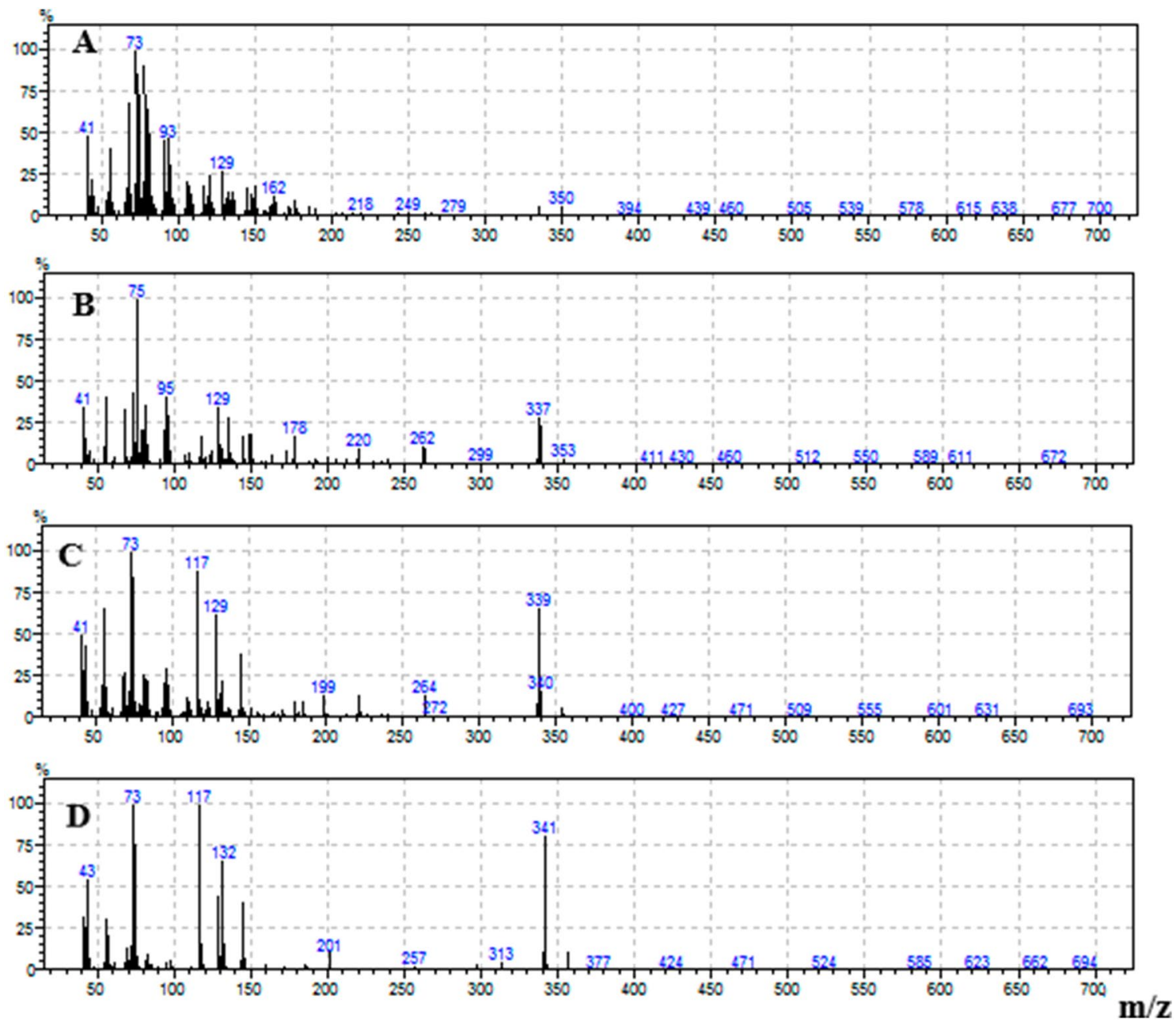

Figure 1. Mass spectra of the trimethylsilyl ester of octadecatrienoic acid, C18:3 (A), octadecadienoic acid C18:2 (B), octadecenoic acid C18:1 (C), octadecanoic acid C18:0 (D).

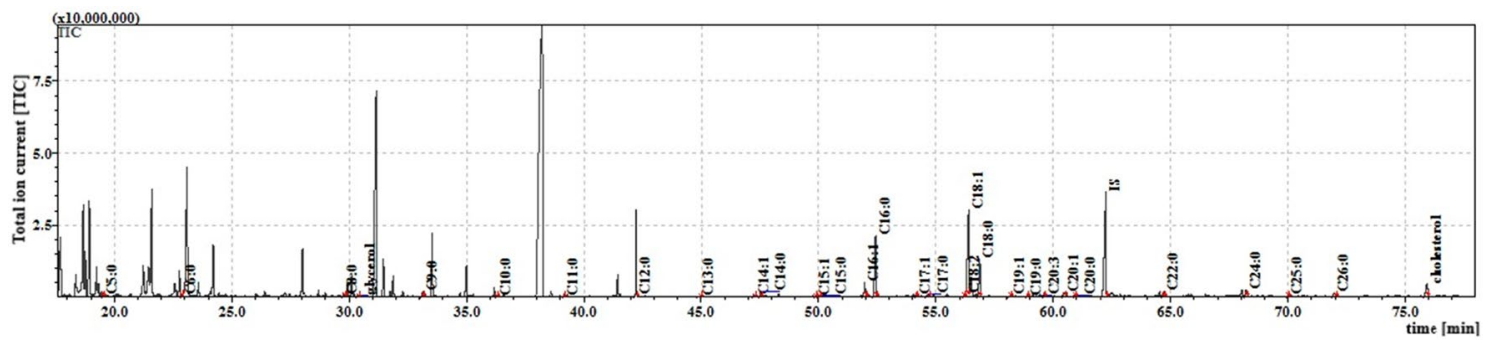

Figure 2. The total ion current (TIC) chromatogram of fatty acids (TMS esters) of the ether extract (Extract I) from S. argyrostoma larvae. Internal standard (IS, 19-methylarachidic acid); fatty acids and molecular ions: pentanoic acid $(\mathrm{C5}: 0, \mathrm{~m} / \mathrm{z}=174)$, hexanoic acid $(\mathrm{C} 6: 0, \mathrm{~m} / \mathrm{z}=188)$, octanoic acid $(\mathrm{C} 8: 0, \mathrm{~m} / \mathrm{z}=216)$, nonanoic acid $(\mathrm{C} 9: 0, \mathrm{~m} / \mathrm{z}=230)$, decanoic acid $(\mathrm{C} 10: 0, \mathrm{~m} / \mathrm{z}=244)$, undecanoic acid $(\mathrm{C} 11: 0, \mathrm{n} / \mathrm{z}=258)$, dodecanoic acid $(\mathrm{C} 12: 0, \mathrm{~m} / \mathrm{z}=272)$, tridecanoic acid $(\mathrm{C} 13: 0, \mathrm{~m} / \mathrm{z}=286)$, tetradecenoic acid $(\mathrm{C} 14: 1, \mathrm{~m} / \mathrm{z}=298)$, tetradecanoic acid $(\mathrm{C} 14: 0, \mathrm{~m} / \mathrm{z}=300)$, pentadecenoic acid $(\mathrm{C} 15: 1, \mathrm{~m} / \mathrm{z}=312)$, pentadecanoic acid $(\mathrm{C} 15: 0, \mathrm{~m} / \mathrm{z}=314)$, hexadecenoic acid $(\mathrm{C} 16: 1, \mathrm{~m} / \mathrm{z}=326)$, hexadecanoic acid $(\mathrm{C} 16: 0, \mathrm{~m} / \mathrm{z}=328)$, heptadecenoic acid $(\mathrm{C} 17: 1, \mathrm{~m} / \mathrm{z}=340)$, heptadecanoic acid $(\mathrm{C} 17: 0, \mathrm{~m} / \mathrm{z}=342)$, octadecadienic acid $(\mathrm{C} 18: 2, \mathrm{~m} / \mathrm{z}=352), 17$-octadecenoic acid (C18:1, $\mathrm{m} / \mathrm{z}=354), 18$-octadecanoic acid $(\mathrm{C} 18: 0, \mathrm{~m} / \mathrm{z}=356)$, nonadecenoic acid $(\mathrm{C} 19: 1, \mathrm{~m} / \mathrm{z}=368)$, nonadecanoic acid (C19:0, $\mathrm{m} / \mathrm{z}=370)$, eicosatrienoic acid $(\mathrm{C} 20: 3, \mathrm{~m} / \mathrm{z}=378)$, eicosenoic acid $(\mathrm{C} 20: 1, \mathrm{~m} / \mathrm{z}=382)$, eicosanoic acid $(\mathrm{C} 20: 0, \mathrm{~m} / \mathrm{z}=384)$, docosanoic acid $(\mathrm{C} 22: 0, \mathrm{~m} / \mathrm{z}=412)$, etracosanoic acid (C24:0, $\mathrm{m} / \mathrm{z}=440)$, pentacosanoic acid $(\mathrm{C} 25: 0, \mathrm{~m} / \mathrm{z}=454)$, hexacosanoic acid $(\mathrm{C} 26: 0, \mathrm{~m} / \mathrm{z}=468)$. 


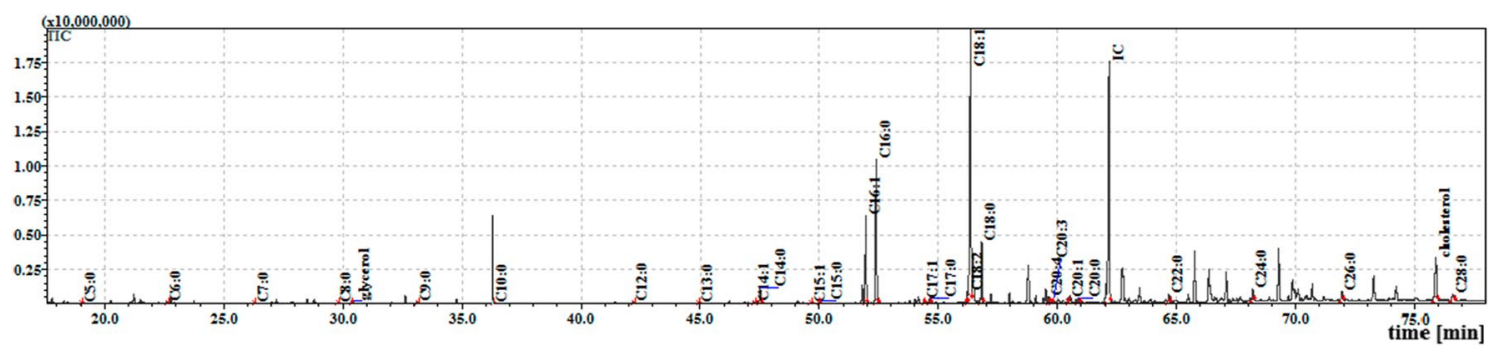

Figure 3. The total ion current (TIC) chromatogram of fatty acids (TMS esters) of the dichloromethane extract (Extract II) from S. argyrostoma pupae. Internal standard (IS, 19-methylarachidic acid); fatty acids and molecular ions: pentanoic acid (C5:0, $\mathrm{m} / \mathrm{z}=174$ hexanoic acid (C6:0, $\mathrm{m} / \mathrm{z}=188)$, heptanoic acid (C7:0, $\mathrm{m} / \mathrm{z}=202)$, octanoic acid $(\mathrm{C} 8: 0, \mathrm{~m} / \mathrm{z}=216)$, nonanoic acid $(C 9: 0, \mathrm{~m} / \mathrm{z}=230)$, decanoic acid $(\mathrm{C} 10: 0, \mathrm{~m} / \mathrm{z}=244)$, dodecanoic acid $(\mathrm{C} 12: 0, \mathrm{~m} / \mathrm{z}=272)$, tridecanoic acid $(\mathrm{C} 13: 0, \mathrm{~m} / \mathrm{z}=286)$, tetradecenoic acid $(\mathrm{C} 14: 1, \mathrm{~m} / \mathrm{z}=298)$, tetradecanoic acid $(\mathrm{C} 14: 0, \mathrm{~m} / \mathrm{z}=300)$, pentadecanoic acid $(\mathrm{C} 15: 0, \mathrm{~m} / \mathrm{z}=314)$, hexadecenoic acid $(\mathrm{C} 16: 1$, $\mathrm{m} / \mathrm{z}=326)$, hexadecanoic acid $(\mathrm{C} 16: 0, \mathrm{~m} / \mathrm{z}=328)$, heptadecenoic acid $(\mathrm{C} 17: 1, \mathrm{~m} / \mathrm{z}=340)$, heptadecanoic acid (C17:0, $\mathrm{m} / \mathrm{z}=342)$, octadecadienic acid $(\mathrm{C} 18: 2, \mathrm{~m} / \mathrm{z}=352)$, octadecenoic acid $(\mathrm{C} 18: 1, \mathrm{~m} / \mathrm{z}=354)$, octadecanoic acid $(\mathrm{C} 18: 0, \mathrm{~m} / \mathrm{z}=356)$, eicosatrienoic acid $(\mathrm{C} 20: 3, \mathrm{~m} / \mathrm{z}=378$, eicosenoic acid $(\mathrm{C} 20: 1, \mathrm{~m} / \mathrm{z}=382)$, eicosanoic acid $(\mathrm{C} 20: 0, \mathrm{~m} / \mathrm{z}=384)$, docosanoic acid $(\mathrm{C} 22: 0, \mathrm{~m} / \mathrm{z}=412)$, tetracosanoic acid $(\mathrm{C} 24: 0, \mathrm{~m} / \mathrm{z}=440)$, hexacosanoic acid (C26:0, $\mathrm{m} / \mathrm{z}=468)$, octacosanoic acid $(\mathrm{C} 28: 0, \mathrm{~m} / \mathrm{z}=496)$.

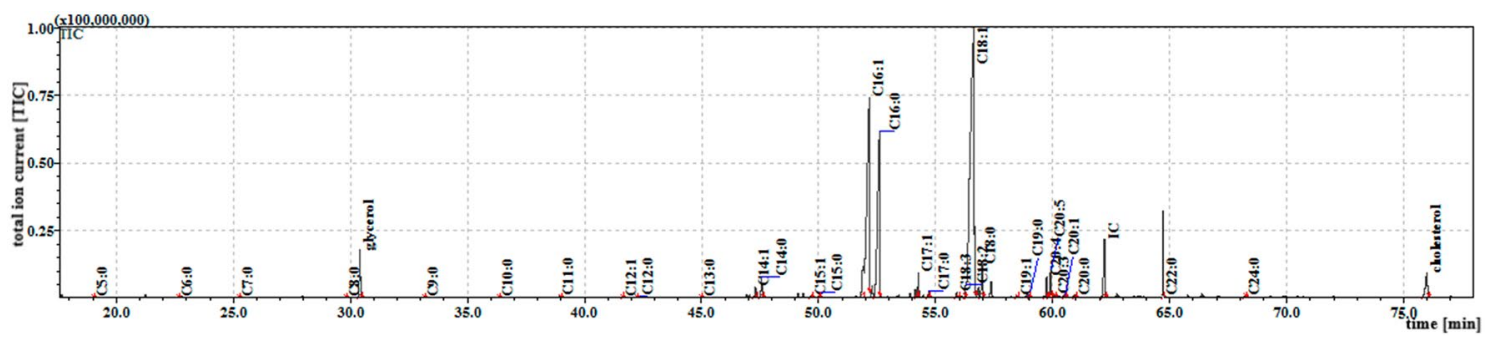

Figure 4. The total ion current (TIC) chromatogram of fatty acids (TMS esters) from sonicated from $S$. argyrostoma adults. Internal standard (IS, 19-methylarachidic acid); fatty acids and molecular ions: pentanoic acid (C5:0, $\mathrm{m} / \mathrm{z}=174$ hexanoic acid (C6:0, $\mathrm{m} / \mathrm{z}=188)$, heptanoic acid (C7:0, m/z=202), octanoic acid (C8:0, $\mathrm{m} / \mathrm{z}=216)$, nonanoic acid $(\mathrm{C} 9: 0, \mathrm{~m} / \mathrm{z}=230)$, decanoic acid $(\mathrm{C} 10: 0, \mathrm{~m} / \mathrm{z}=244)$, undecanoic acid $(\mathrm{C} 11: 0$, $\mathrm{m} / \mathrm{z}=258)$, dodecenoic acid $(\mathrm{C} 12: 1, \mathrm{~m} / \mathrm{z}=270)$, dodecanoic acid $(\mathrm{C} 12: 0, \mathrm{~m} / \mathrm{z}=272)$, tridecanoic acid $(\mathrm{C} 13: 0$, $\mathrm{m} / \mathrm{z}=286)$, tetradecenoic acid $(\mathrm{C} 14: 1, \mathrm{~m} / \mathrm{z}=298)$, tetradecanoic acid $(\mathrm{C} 14: 0, \mathrm{~m} / \mathrm{z}=300)$, pentadecenoic acid $(\mathrm{C} 15: 1, \mathrm{~m} / \mathrm{z}=312)$, pentadecanoic acid $(\mathrm{C} 15: 0, \mathrm{~m} / \mathrm{z}=314)$, hexadecenoic acid $(\mathrm{C} 16: 1, \mathrm{~m} / \mathrm{z}=326)$, hexadecanoic acid $(\mathrm{C} 16: 0, \mathrm{~m} / \mathrm{z}=328)$, heptadecenoic acid $(\mathrm{C} 17: 1, \mathrm{~m} / \mathrm{z}=340)$, heptadecanoic acid $(\mathrm{C} 17: 0, \mathrm{~m} / \mathrm{z}=342)$, octadecatrienoic acid $(\mathrm{C} 18: 3, \mathrm{~m} / \mathrm{z}=350)$, octadecadienic acid $(\mathrm{C} 18: 2, \mathrm{~m} / \mathrm{z}=352)$, octadecenoic acid $(\mathrm{C} 18: 1$, $\mathrm{m} / \mathrm{z}=354)$, octadecanoic acid $(\mathrm{C} 18: 0, \mathrm{~m} / \mathrm{z}=356)$, nonadecenoic acid $(\mathrm{C} 19: 1, \mathrm{~m} / \mathrm{z}=368)$, monadecanoic acid (C19:0, $\mathrm{m} / \mathrm{z}=370)$, eicosatetraenoic acid $(\mathrm{C} 20: 4, \mathrm{~m} / \mathrm{z}=376)$, eicosapentaenoic acid $(\mathrm{C} 20: 5, \mathrm{~m} / \mathrm{z}=374)$, eicosatrienoic acid $(C 20: 3, \mathrm{~m} / \mathrm{z}=378$, eicosenoic acid $(\mathrm{C} 20: 1, \mathrm{~m} / \mathrm{z}=382)$, eicosanoic acid $(\mathrm{C} 20: 0, \mathrm{~m} / \mathrm{z}=384)$, docosanoic acid $(\mathrm{C} 22: 0, \mathrm{~m} / \mathrm{z}=412)$, tetracosanoic acid $(\mathrm{C} 24: 0, \mathrm{~m} / \mathrm{z}=440)$.

Significant differences regarding the presence of individual FFAs were observed regarding the between developmental stages. C23:0 and C25:0 were observed only in larvae, whereas C28:0 was detected only in the cuticle of pupae. In turn, C12:1 and C18:3 were present only in internal extracts from adults. Interestingly, several FFAs present in larvae and adults were absent from pupae: C11:0, C19:1, and C19:0 absent from both extracts; C20:4 and C20:5 absent from the cuticle; C13:0, C20:3, C20:1, and C26:0 absent from the internal extract.

Glycerol and cholesterol were observed in all extracts. However, glycerol content was higher in the extract from the adults $(23.366 \pm 0.632 \mu \mathrm{g} / \mathrm{g}$ insect body mass in the cuticular extract and $93.437 \pm 2.506 \mu \mathrm{g} / \mathrm{g}$ insect body mass in the internal extract) and larvae $(3.064 \pm 0.071 \mu \mathrm{g} / \mathrm{g}$ insect body mass in the cuticular extract and $30.370 \pm 0.517 \mu \mathrm{g} / \mathrm{g}$ insect body mass in the internal extract) than from the pupae $(0.316 \pm 0.021 \mu \mathrm{g} / \mathrm{g}$ insect body mass in the cuticular extract and $0.3202 \pm 0.014 \mu \mathrm{g} / \mathrm{g}$ insect body mass in the internal extract). In larvae and adults, the glycerol concentrations were ten-times and four-times higher in the internal extracts than the cuticle, while in pupae, both concentrations were nearly equal. The results have been showed in Table 3 .

The highest concentration of cholesterol was observed in the extracts from adult cuticular $(33.256 \pm 0.514 \mu \mathrm{g} / \mathrm{g}$ insect body mass) and internal extracts $(92.327 \pm 0.509 \mu \mathrm{g} / \mathrm{g}$ insect body mass); the highest content was observed inside the insect body. In contrast, in the larval and pupal extracts, a higher content of cholesterol was observed in the cuticular fractions of larval $(4.527 \pm 0.000 \mu \mathrm{g} / \mathrm{g}$ of insect body) and pupal extracts $(7.604 \pm 0.174 \mu \mathrm{g} / \mathrm{g}$ of insect body) than in their corresponding internal fractions: $2.958 \pm 0.015 \mu \mathrm{g} / \mathrm{g}$ insect body mass in larvae and $5.676 \pm 0.196 \mu \mathrm{g} / \mathrm{g}$ insect body mass in pupae. The results have been showed in Table 3 . 


\begin{tabular}{|l|l|l|l|l|l|l|}
\hline \multirow{2}{*}{ Sterols } & \multicolumn{3}{|l|}{ Larvae } & Pupae & \multicolumn{2}{l|}{ Adults } \\
\cline { 2 - 7 } & Cuticular & Internal & Cuticular & Internal & Cuticular & Internal \\
\hline Glycerol & $3.064 \pm 0.109^{\mathrm{A}}$ & $30.369 \pm 0.517^{\mathrm{A}-\mathrm{C}}$ & $0.316 \pm 0.021^{\mathrm{B}}$ & $0.202 \pm 0.014^{\mathrm{C}}$ & $25.366 \pm 0.632^{\mathrm{A}-\mathrm{C}}$ & $93.437 \pm 2.506^{\mathrm{A}-\mathrm{C}}$ \\
\hline Cholesterol & $4.527 \pm 0.038^{\mathrm{A}}$ & $2.958 \pm 0.015^{\mathrm{A}}$ & $7.604 \pm 0.174^{\mathrm{A}}$ & $5.676 \pm 0.196^{\mathrm{A}}$ & $33.256 \pm 0.514^{\mathrm{A}}$ & $92.327 \pm 0.509^{\mathrm{A}}$ \\
\hline
\end{tabular}

Table 3. Glycerol and cholesterol contents in the cuticular and internal lipids extracted from Sarcophaga argyrostoma $[\mu \mathrm{g} / \mathrm{g}$ of body mass $\pm \mathrm{SD}]$. FFA free fatty acids, $S D$ standard deviation, $N D$ not detected; statistically significant differences are marked with the same letters (ANOVA, Test HSD Tukey, p<0.05), see Table S1 for raw data.

\section{Discussion}

The FFAs comprise a huge and diverse group of lipids. Our present findings demonstrate high quantitative and qualitative FFA content diversity between the three developmental stages: larvae, pupae and imago. They also confirm the occurrence of metamorphosis-related changes in the FFA profiles in S. argyrostoma as observed in other insect species ${ }^{37-44}$.

The differences in distribution of fatty acids in the body of the insect are summarised in Table 2. The agedependent differences in cuticular lipid content have been observed in S. bullata imagoes: FFAs were found to constitute $26 \%$ of all cuticular lipids in new-borns and $45 \%$ in 7 -day-old flies, suggesting that lipid synthesis or transport to the cuticle surface may be incomplete in newly-emerged adults. The author also proposes that lipid transport occurs primarily through the unhardened cuticle of newly-emerged adults, and that transport is essentially complete by the time the adult cuticle is fully hardened ${ }^{56}$. FFAs are also used as precursors of cuticular hydrocarbons. Oenocyte-directed RNAi knock-down of D. melanogaster CYP4G1 or NADPH-cytochrome P450 reductase results not only in flies deficient in cuticular hydrocarbons, but also in the accumulation of midchain fatty acids, which might suggest that they play a role in hydrocarbon synthesis ${ }^{57}$.

The results of the GC-MS analysis indicate that the extracts from adults possess higher FFA content than in preimaginal stages of flies, which is in accordance with previous findings ${ }^{26}$ in Sarcophaga carnaria. Sun and Brookes also report a lower level of FFA in the fat body of Sarcophaga bullata larvae (from 0.93 to $2.92 \%$, depending on age) than in adults ${ }^{58}$; they also note that $\mathrm{C} 18: 1>\mathrm{C} 16: 0>\mathrm{C} 18: 0>\mathrm{C} 16: 1$ FFAs predominated in three-day-old larvae, and C18:1 > C16:0 > C16:1:C18:2 in nine-day-old larvae, and that the amount of C18:2 and C16:1 increased, and C18:0 decreased, during six days of rearing ${ }^{58}$.

In the present study, $\mathrm{C} 18: 1>\mathrm{C} 16: 1>\mathrm{C} 16: 0>\mathrm{C} 18: 0$ predominate in both cuticular and internal extracts from larvae and adults, while 18:1 >C16:0 > C16:1 > C18:0 predominate in pupae; those FFAs have also found to be characteristic of Dipter ${ }^{59,60}$. The dominant FFA is C18:1 in all extracts, with the highest proportions being found in the adult extracts ( $47.78 \%$ in cuticular and $49.14 \%$ in internal) and the internal extracts of pupae (47.85\%). In previous studies, higher proportions of C18:1 have been described in the internal extracts from larvae (55.9\%) and pupae $(58.9 \%)$ of $S$. carnaria ${ }^{26}$. In S. bullata, lower levels of C18:1 were found in the cuticular extracts of adults; in addition, the C18:1 levels in the cuticular extract increased during adulthood from $29.0 \%$ in new-born and $34.3 \%$ in seven-day-old adults, while C16:1 decreased from 32.5 to $21.6 \%{ }^{56}$.

In all extracts, the predominant FFA was found to be C18:1. One example of a C18:1 FFA is oleic acid. It has many biological properties, including the ability to provide a wide temperature window for growth. It provides the best environment for critical membrane proteins such as membrane ATPases, which function at optimum levels when oleic acid is present in the cell membrane ${ }^{61}$; therefore, an increase in oleic acid level in response to, or in preparation for low temperatures, may maintain correct fluidity of the membrane without sacrificing the delicate balance needed to optimize the function of sensitive membrane proteins. Higher proportions of C18:1 have been found as an adaptation to low temperatures in Eurosta solidaginis ${ }^{62}$, Dolycoris baccarum and Piezodorus lituratus $^{63}$ and $S$. similis ${ }^{64}$. As oleic acid is energetically more favourable to manufacture than linoleic acid, due to it having one less double bond, insects that upregulate oleic acid rather than linoleic acid for low temperature use may be preserving finite energy reserves while still gaining the benefit of a wide window of fluidity ${ }^{65}$. The high amount of C18:1 observed in S. argyrostoma might be an example of adaptation to cold.

Polyunsaturated fatty acids (PUFA) are usually associated with biomembranes as phospholipid fatty acids. The proportion and composition of 20:5, 20:4 and 20:3 in the membranes, cuticle and so on vary according to life stage and tissue type ${ }^{66}$. Higher concentrations of C20:5 (1.59\% of FFA content) and C20:4 (1.12\%) were observed in the internal extracts in the present study; they are thought to be precursors of prostaglandins, leukotrienes and thromboxanes ${ }^{67-70}$. Various metabolites of C20:4 (arachidonic acid), known as eicosanoids, stimulate oviposition in crickets, regulate the function of Malpighian tubules in mosquitoes or ants, and control thermoregulation in cicadas $^{71}$. They also play crucial roles in the mediation of insect cellular and humoral immunity ${ }^{72,73}$; for example, in S. argyrostoma, they were found to mediate and coordinate the biosynthesis of NO and lysozyme in response to bacterial challenge ${ }^{27}$, and to participate in the LPS-dependent activation of the IMD pathway in Sarcophaga peregrina $a^{74}$. In a study of the internal extract of S. carnaria, Gołębiowski and co-workers found C20:5 to be present at 90-times higher concentrations in females than males; they propose that the compounds may play an important role in vitellogenesis ${ }^{26}$. Clements and co-workers ${ }^{75}$ propose that arachidonic acid may play a role in the resistance of the Colorado potato beetle, Leptinotarsa decemlineata to neonicotinoid insecticide, and suggest that this may be associated with its regulatory role in cytochrome P450-dependent insecticide detoxification pathways. In the present study, a high concentration of C20:4 was observed in the extracts from the adults, which might suggest that $S$. argyrostoma is resistant to chemical insecticides; however, more detailed research is needed to confirm this. 
The FFAs in the insect cuticle have also been identified as resistance factors against fungal infection; for example, Gołębiowski and co-workers report that cuticular FFAs play a role in resistance to fungal infection by the flies Calliphora vicina, Lucilia sericata, C. vomitoria and S. carnaria ${ }^{26,39-41,76,77}$. Also, literature data postulate that the chemical composition of cuticular FFAs may influence the susceptibility of cockroaches (Blatella germanica, Blatta orientalis) to infection by the fungus Metarhizium anisopliae ${ }^{78}$ and by Conidiobolus coronatus ${ }^{79}$. Additionally, Smith and Grula indicate that cuticular FFAs in corn earworm larvae (Heliothis zea) can inhibit the germination and growth of Beauveria bassiana ${ }^{80}$. These examples illustrate the significant role played by cuticular FFAs in resistance or susceptibility to entomopathogens.

In the present work, higher levels of C9:0, C18:0 and C22:0 were found in the cuticular fractions of larvae, pupae and adults than the internal fractions. Of these, C9:0 and C18:0 have been found to inhibit the germination of C. coronatus spores ${ }^{81}$. Wrońska and co-workers ${ }^{43}$ report a correlation between the concentration of C9:0 and C18:0 in the cuticle of Galleria mellonella larvae, pupae and imagoes, and the activity of C. coronatus enzyme cocktail. In addition, Boguś and co-workers ${ }^{82}$ report a correlation between the concentration of C9:0, C18:0 and C22:0 in the cuticle of four medical and veterinary important flies: C. vomitoria, C. vicina, L. sericata and Musca domestica, and the enzymatic activity of $C$. coronatus.

Lipid accumulation and mobilisation is particularly important for the radical reconstruction of body structure and its biochemistry in holometabolous insects such as the Sarcophagae. However, these flies can also be larviparous, meaning that the egg develops internally, and females then give birth to first-instar larvae ${ }^{83}$.

The lipid content of holometabolous insects increases steadily during larval development, reflecting not only the metabolic requirements of the larva, but also the need to accumulate reserves for maintenance during metamorphosis ${ }^{84}$. However, in the present study, a higher concentration of particular FFAs was observed in the cuticular fraction; the levels of C9:0, C17:0, C18:0 and C23:0 were twice as high, C22:0, C24:0 and C26:0 were three times as high and C25:0 was five times as high. It is unusual to find odd-numbered fatty acids in insects, and as such, the presence C25:0 and C23:0 in the larval extracts merits further discussion. Pentacosanoic acid methyl ester is used as a pheromone by the European paper wasp Polistes dominulus for nest discrimination ${ }^{85}$. The C25:0 fatty acid has been found in both larval-larval ( $0.3 \%$ of FFA content) and larval-pupal ( $0.1 \%$ of FFA content) cuticular extracts from Dendrolimus pini exuviae; in contrast, C23:0 has only been found in in larvallarval extracts $(0.1 \% \text { of FFA content })^{86}$. C23:0 has also been described in the whole-body extracts of Allomyrina dichotoma $^{87}$, Protaetia brevitarsis ${ }^{88}$, Tenebrio molitor ${ }^{89}$ and in Cirina ford $a^{90}$ larvae and Teleogryllus emma adults ${ }^{89}$, which are used as food in Asia.

Cholesterol was also found in higher levels in the cuticular extracts of the tested larvae. This contrasts with C. vicina, M. domestica and S. carnaria, where higher levels have been recorded in the internal extract. In addition, in contrast to the present study on S. argyrostoma, it has previously been found to be absent from cuticular extracts of $S$. carnaria larvae ${ }^{38}$. In the present study, glycerol was found to be present at higher concentrations in the internal extract, which is similar the distribution of glycerol in M. domestica larvae ${ }^{38}$.

During metamorphosis, most larval tissues decompose and adult structures are synthesized de novo from imaginal discs ${ }^{91-93}$. This process is dependent upon energy reserves, lipids for example, and anabolic precursors accumulate during larval growth ${ }^{84}$. Our present findings indicate a wide diversity of FFAs in the pupal stage; however, lower total FFA content was observed in both the internal and cuticular extracts of the pupal stage, compared with other developmental stages. A number of FFAs were found to be present at higher concentrations in the cuticular extract than the internal one, particularly C9:0, C12:0, C14:0, C18:0 and C22:0, each of which was present at twice the level in the cuticle. Wrońska and co-workers ${ }^{43}$ report a high positive correlation between the concentration of C12:0 in the pupal cuticle of G. mellonella and the efficiency of entomopathogenic fungus C. coronatus chitinases and lipases in degrading it. In addition, similar to the present findings, S. carnaria pupae demonstrated a lack of C11:0, C19:1 and C20:4 in cuticular extracts and C20:1 in internal extracts; however, all FFAs were present in extracts from the larvae ${ }^{26}$.

In addition, the concentration of cholesterol was higher in the cuticular extracts in the present study, in contrast to extracts from $M$. domestica, S. carnaria and C. vicina pupa ${ }^{38}$. Glycerol was found to be present at very similar concentrations in the cuticular and internal extracts of the tested pupae, as previously observed in extracts from C. vicina pupae ${ }^{38}$. Lower amounts of internal FFAs were recorded, which might be due to disintegration of larval fat body in the pupal stage ${ }^{94}$.

An interesting finding was the presence of the long-chain FFA C28:0 on the surface of the cuticle of pupae, which is quite unique for insects. It is an aliphatic primary acid which has been shown to be an antibiofilm and anti-adherence agent against Streptococcus mutans ${ }^{95}$; it has so far only been detected in the cuticular wax of the honey bee Apis mellifer $a^{96}$ and in the cuticular fraction from larvae and pupae of $D$. pini ${ }^{86}$. It is important to note that this FFA is absent in extracts from species which are also consider as significant tools in forensics, such as $C$. vicina $a^{97}$, C. vomitoria ${ }^{40}$ and S. carnaria ${ }^{26}$. However, C28:0 has been found in chloroform extracts from C. vicina (C. erythrocephala) pupae by electron diffraction ${ }^{98}$.

The advantage of holometabolous development is the specialisation of stages: larvae for feeding and growth, and adults for reproduction. However, there are some examples of holometabolous insects, such as blood-feeding mosquitos, which require blood meal to obtain protein or lipids to achieve, or enhance, reproductive success. Research on S. crassipalpis has shown that lipids derived from adult dietary components constitute half of the storage materials of eggs, and these are used as an energy supply for the developing embryos ${ }^{99}$. The balance between lipogenesis and lipolysis is tightly regulated in insects, to match energy needs that vary in response to the changes in the environment ${ }^{100-102}$. FFAs are main source of energy for muscles during flight.

In the adult fly extracts, higher concentrations of particular short-FFA were observed in the cuticle than in the internal extracts; for example, the concentration of C5:0 was four-times higher in the cuticle. However, the opposite was observed in case of middle and long-chain FFAs: higher amounts of particular FFA was detected inside the body, particularly C20:4 and C20:5. Also, the cholesterol and glycerol concentrations were higher in 
the internal extracts; a similar situation was observed in extracts from M. domestica, S. carnaria and C. vicina flies; however, higher concentrations were observed in the cuticular fraction for male C. vicina ${ }^{38}$.

The internal extract also included two unsaturated FFAs: C12:1 (0.02\% of all FFAs) and C18:3 (0.37\% of all FFAs). C12:1 has been found in extracts from the larvae, pupae and adults (both female and male) from two species: Dermestes ater and Dermestes maculatus, which are highly resistant to infection by the entomopathogen fungus C. coronatus $^{42}$, as well as in cuticular extracts from Schistocerca gregaria ${ }^{103}$. The presence of C18:3 was detected in phospholipids in Sarcophaga similis ${ }^{64}$ and in extracts from Culex pipiens mosquito, where it allowed adults to stand or hop on the medium surface ${ }^{104}$ and support flight at emergence; however, it was less effective than arachidonic acid $(\mathrm{C} 20: 4)^{105}$. C18:3 is required by Lepidoptera and Hymenoptera to achieve complete metamorphosis ${ }^{106}$ and has been used as a precursor of female moth sex pheromones ${ }^{107}$.

The fatty acid contents of insects can vary according to growth stage, temperature and dietary regime. It is well know that in the environment, flesh flies feed on nectar, fruit juice, decomposing matter such as excrement, and carrion as sources of protein ${ }^{108-110}$. Valverde-Castro and co-workers report the presence of high population densities of Sarcopagiae flies in places with decomposing fish, whose flesh is associated with high fat and protein content; both are needed by female flies for developing eggs, and for the growth and development of first instar larva ${ }^{5}$. Insects from fly families like the Muscidae, Calliphoridae, Drosophilidae, and Stratiomyidae can develop on media containing human faeces and fruits; however, the authors note that the nutrient levels from that source are insufficient for the larval development of the Sarcophaginae ${ }^{5}$. In the present work, all adults had access to both meat, i.e. beef, and sugar. Studies have shown that more than $30 \%$ of the fatty acid content in beef is composed of oleic acid ${ }^{111-113}$, which might explain the high level of C18:1 in the extracts from adult flies. In addition, beef is a popular meat used for feeding Diptera flies, and high levels of C18:1 have also been observed in extracts from adult $L$. sericat $a^{39}$ or C. vomitoria ${ }^{40}$. The higher levels of FFA in the extracts from adults might be explained also by the conversion of saccharose (sugar) to lipids ${ }^{114}$. Literature data indicates that female Sarcophaga start to feed on sugar after emergence and begin to feed on meat after three days, and that meat feeding is cyclic ${ }^{115}$. The insects are also able to take up dietary C20:5, which can alter the overall FFA profile of tissue phospholipids in lengthy feeding experiments ${ }^{116-118}$; in addition, dietary administration of C20:5 might reverse the inhibitory effect of dexamethasone (an inhibitor of eicosanoid formation) during viral infection in the larvae of the parasitic wasp Pimpla turionellae ${ }^{119}$.

Although sterols are essential substrates for insect steroid hormone (ecdysteroid) synthesis ${ }^{120}$, insects do not have the ability to synthesize sterols de novo due to a deficiency of the necessary enzymes ${ }^{121,122}$; therefore, their diet is their main source. Research has indicated that some insects demonstrate a preference toward some FFAs in the diet. For example, the adult mosquitoes Aedes aegypti $i^{123}$ and Anopheles gambi $i^{124}$, and the nymphal bug Triatoma infestans ${ }^{125}$ are attracted by specific FFAs (mixed with L-lactic acid), and that some FFAs might discourage insects, like flies ${ }^{126}$ or mosquitoes ${ }^{127}$. However, this preference for some FFAs could change over the course of development; for example, Drosophila melanogaster larvae prefer unsaturated FFAs whereas adults prefer saturated FFAs ${ }^{128}$.

Although diet generally affects the fatty acid profiles of insects, exceptional cases can occur. The biosynthesis of saturated palmitic (C16:0) and stearic acids (C18:0) and monounsaturated oleic acid (C18:1) seems to be widespread among insects, and accordingly, these fatty acids are the most abundant in their bodies ${ }^{40,46}$. Some insects from the Hymenoptera ( $N$. vitripennis, for example) can synthesize the C18:2 FFA linoleic acid from oleic acid, thanks to presence of D12-desaturase, an enzyme, which is responsible for inserting a double bound at the D12-position ${ }^{129}$.

One of the important roles of health officials, particularly in tropical and subtropical regions, is the control of fly populations in urban and rural communities. Parasitoid wasps in the Order Hymenoptera (for example N. vitripennis) are regarded as biological control agents of flies ${ }^{8,130-133}$. N. vitripennis wasps have been found to demonstrate a strong preference for Sarcophaga pupae, including S. argyrostoma, due to the greater production and rapid development of wasp pathogeny during infection by ${ }^{6,134,135}$.

The host preference might be connected with lipid metabolism: as parasitoid wasps are supposed to have lost their potential for lipogenesis during evolution due to environmental compensation, host lipids may well be essential and limiting factors for developing larvae ${ }^{136,137}$. In addition, Thompson and Barlow propose that the level of FFAs in parasitic Hymenoptera is determined by the FFA levels in their host lipid profile ${ }^{138}$. Similarly, research on parasitized S. bullata or S. crassipalpis pupae have shown increasing expression of genes involved in lipid biosynthesis and higher lipid content after venom injection ${ }^{134,139-142}$. Hyperlipidaemia is also observed after administration of venom of Euplectrus separate to lepidopteran larva Pseudaletia separate ${ }^{143}$.

Our present findings illustrate the great diversity of FFAs between insect development stages: C23:0 and C25:0 are only present in larvae, C28:0 in the pupal cuticle, and C12:1 and C18:3 in the internal extracts from adults. This variation, occurring as a result of the remodelling processes of holometabolic insects and their adaptation to environment conditions might be a useful tool for the distinction of sarcophoids. Our findings regarding the chemical composition of the fatty acids of S. argyrostoma may play an important role in further studies on other significant lipid components of flies intended to improve our understanding of the taxonomy and physiology of insects, and thus may have a great impact on medical, veterinary, toxicology and forensic science.

\section{Methods}

Insect. S. argyrostoma were reared at $25^{\circ} \mathrm{C}$ with $70 \%$ relative humidity and a 15:9 h photoperiod. The larvae were fed on beef ad libitum. The flies formed a puparium 14 days after hatching, and the adults emerged 14 days later. The species was confirmed by prof. Krzysztof Szpila from the Chair of Ecology and Biogeography (Nicolaus Copernicus University in Toruń, Poland). Post-feeding third instar larvae, freshly emerged pupae and 6-day-old sexually mature adults were used for lipid extraction. The sixth generation of insects were used in the study. 
Extraction of free fatty acids (FFAs). Cuticular and internal lipid components of insects were extracted, separated and analysed by GC-MS. The method of extraction was based on literature data (for example ${ }^{43,44,76,79,144}$ ). Lipids from larvae, pupae and adults were extracted first in $20 \mathrm{ml}$ of petroleum ether (Merck Millipore, Germany) for $5 \mathrm{~min}$ (extract I) and then again in $20 \mathrm{ml}$ of dichloromethane (Merck Millipore, Germany) for $5 \mathrm{~min}$ (extract II) to yield cuticular lipids. The insects were sonicated $(1 \mathrm{~min})$ with dichloromethane to produce Extract III containing internal lipids. The extracts were placed in glass flasks and evaporated under nitrogen.

Derivatization method. One mg of each sample and $10 \mu \mathrm{l} 19$-methylarachidic acid (1 mg/ml; Merck Millipore) were silylated with $100 \mu \mathrm{l}$ of N,O-Bis(trimethylsilyl)trifluoroacetamide (BSTFA): chlorotrimethylsilane (TMCS) (99:1) (Merck Millipore) mixture for one hour at $100{ }^{\circ} \mathrm{C}$ to obtain trimethylsilyl esters (TMS) of FFAs. The TMS values of the fatty acids were then analysed by GC-MS.

GC-MS analyses. The GC-MS analyses were carried out on a GCMS-QP2010 system with mass detector (Shimadzu, Japan). Helium was used as the carrier gas at a column head pressure of $65.2 \mathrm{kPa}$. A DB-5 MS (Zebron, Phenomenex, USA) column was used (thickness $0.25 \mu \mathrm{m}$, length $30 \mathrm{~m}$, diameter $0.25 \mu \mathrm{m}$ ). The column oven temperature cycle was maintained at $80^{\circ} \mathrm{C}$ for $3 \mathrm{~min}$, then ramped from 80 to $310^{\circ} \mathrm{C}$ at $4{ }^{\circ} \mathrm{C} / \mathrm{min}$; the final temperature was then held for $10 \mathrm{~min}$. The ion source temperature was $200^{\circ} \mathrm{C}$ and the interface temperature was $310^{\circ} \mathrm{C}$. Split mode was used with a split ratio of 10 . All compounds were identified based on fragmentation patterns and mass-to-charge ions of the TMS derivatives and the NIST 11 library. The mass spectra of the fatty acid trimethylsilyl esters comprised M+(molecular ion), [M-15] +, and fragment ions at m/z 117, 129, 132, and 145. GC analysis used 19-methylarachidic acid (1 mg/ml; Merck, Germany) as an internal standard (IS). The content of the compounds in the analyzed samples was calculated from the chromatogram peak areas. The results were expressed as a means standard deviation of three GC/MS analyse. Response factors of one were assumed for all constituents. The method is based on literature data ${ }^{43,44,76,79,144}$.

Statistics. The findings were tested by the one-way analysis of variance (ANOVA). Tukey's test was used for post hoc analysis. Each test was performed separately. All analyses were performed using Statistica 6 software (StatSoft Polska, Poland). Differences were significant at $\mathrm{p}<0.05$.

Received: 17 July 2020; Accepted: 30 September 2020

Published online: 15 October 2020

\section{References}

1. De Mello-Patiu, C. A. Family Sarcophagidae. Zootaxa 4122, 884-903 (2016).

2. Szpila, K., Mądra, A., Jarmusz, M. \& Matuszewski, S. Flesh flies (Diptera: Sarcophagidae) colonising large carcasses in Central Europe. Parasitol. Res. 114, 2341-2348 (2015).

3. Vilte, R., Gleiser, R. M. \& Horenstein, M. B. Necrophagous fly assembly: Evaluation of species bait preference in field experiments. J. Med. Entomol. 57, 437-442 (2020).

4. Povolny, D. \& Verves, Y. The Flesh-Flies of Central Europe (Insecta, Díptera, Sarcophagidae).Spixiana (F. Pfeil, 1997).

5. Valverde-Castro, C., Buenaventura, E., Sánchez-Rodríguez, J. D. \& Wolff, M. Flesh flies (Diptera: Sarcophagidae: Sarcophaginae) from the colombian guajira biogeographic province, an approach to their ecology and distribution. Zoologia34, (2017).

6. Desjardins, C. A., Perfectti, F., Bartos, J. D., Enders, L. S. \& Werren, J. H. The genetic basis of interspecies host preference differences in the model parasitoid Nasonia. Heredity 104, 270-277 (2010).

7. Rivers, D. B. \& Denlinger, D. L. Developmental fate of the flesh fly, Sarcophaga bullata, envenomated by the pupal ectoparasitoid, Nasonia vitripennis. J. Insect Physiol. 40, 121-127 (1994).

8. Khoobdel, M., Sobati, H., Dehghan, O., Akbarzadeh, K. \& Radi, E. Natural host preferences of parasitoid wasps (Hymenoptera: Pteromalidae) on synanthropic flies. Eur. J. Transl. Myol. 29, 2 (2019).

9. Zaglool, D. A. M., Tayeb, K., Khodari, Y. A. W. \& Farooq, M. U. First case report of human myiasis with Sarcophaga species in Makkah city in the wound of a diabetic patient. J. Nat. Sci. Biol. Med. 4, 225-228 (2013).

10. Gillung, J. P. \& Borkent, C. J. Death comes on two wings: a review of dipteran natural enemies of arachnids. J. Arachnol. 45, 1-19 (2017).

11. D’Bastiani, E. et al. How deadly sarcophagid fly larvae are for anurans? New interactions and review to Neotropical region. Parasitol. Res. 119, 1415-1422 (2020).

12. Graczyk, T. K., Knight, R. \& Tamang, L. Mechanical transmission of human protozoan parasites by insects. Clin. Microbiol. Rev. 18, 128-132 (2005).

13. McKillup, S. C., McKillup, R. V. \& Pape, T. Flies that are parasitoids of a marine snail: The larviposition behaviour and life cycles of Sarcophaga megafilosia and Sarcophaga meiofilosia. Hydrobiologia 439, 141-149 (2000).

14. Coupland, J. B. \& Barker, G. M. Diptera as predators and parasitoids of terrestrial gastropods, with emphasis on Phoridae, Calliphoridae, Sarcophagidae, Muscidae and Fanniidae. in Natural enemies of terrestrial molluscs (ed. Barker, G. M.) 85-158 (CAB International, Cambridge, 2009). https://doi.org/10.1079/9780851993195.0085

15. Pezzi, M. et al. Facultative myiasis of domestic cats by Sarcophaga argyrostoma (Diptera: Sarcophagidae), Calliphora vicina and Lucilia sericata (Diptera: Calliphoridae) in northern Italy. Parasitol. Res. 116, 2869-2872 (2017).

16. Giangaspero, A. et al. Wound myiasis caused by Sarcophaga (Liopygia) argyrostoma (Robineau-Desvoidy) (Diptera: Sarcophagidae): Additional evidences of the morphological identification dilemma and molecular investigation. Sci. World J.2017 (2017).

17. Blazar, J., Allard, M. \& Lienau, E. K. Insects as vectors of foodborne pathogenic bacteria. Terr. Arthropod Rev. 4, 5-16 (2011).

18. de Souza, C. R. \& Von Zuben, C. J. Synanthropy of Sarcophagidae (Diptera) in southeastern Brazil. Neotrop. Entomol. 45, 637-641 (2016).

19. De Clerck, D., Eechaute, W., Leusen, I., Diederik, H. \& De Loof, A. Identification of testosterone and progesterone in hemolymph of larvae of the fleshfly Sarcophaga bullata. Gen. Comp. Endocrinol. 52, 368-378 (1983).

20. Bil, M., Broeckx, V., Landuyt, B. \& Huybrechts, R. Differential peptidomics highlights adipokinetic hormone as key player in regulating digestion in anautogenous flesh fly, Sarcophaga crassipalpis. Gen. Comp. Endocrinol. 208, 49-56 (2014). 
21. Sim, C. \& Denlinger, D. L. Insulin signaling and the regulation of insect diapause. Front. Physiol. 4, 189 (2013).

22. Reynolds, J. A., Peyton, J. T. \& Denlinger, D. L. Changes in microRNA abundance may regulate diapause in the flesh fly Sarcophaga bullata. Insect Biochem. Mol. Biol. 84, 1-14 (2017).

23. Flannagan, R. D. et al. Diapause-specific gene expression in pupae of the flesh fly Sarcophaga crassipalpis. Proc. Natl. Acad. Sci. USA 95, 5616-5620 (1998).

24. Barbosa, T. M., Cruz, M. R. P., Pontes, W. J. T. \& Vasconcelos, S. D. Aspects of the reproductive behaviour and development of two forensically relevant species, Blaesoxipha (Gigantotheca)stallengi (Lahille, 1907)and Sarcophaga (Liopygia)ruficornis (Fabricius, 1794)(Diptera: Sarcophagidae). Rev. Bras. Entomol. 63, 124-129 (2019).

25. Amer, M., Shehata, A., Hammad, K., Hasballah, A. \& Saed, S. Antimicrobial Activity of Sarcophaga carnaria (Diptera: Sarcophagidae) Maggots' Body Extracts. Egypt. Acad. J. Biol. Sci. G. Microbiol. 11, 23-33 (2019).

26. Gołębiowski, M. et al. The antifungal activity of fatty acids of all stages of Sarcophaga carnaria L. (Diptera: Sarcophagidae). Microbiol. Res. 169, 279-286 (2014).

27. Mohamed, A. A., Ali, M. M., Dorrah, M. A. \& Bassal, T. T. M. Mediation of inducible nitric oxide and immune-reactive lysozymes biosynthesis by eicosanoid and biogenic amines in flesh flies. Int. J. Trop. Insect Sci. 38, 93-104 (2018).

28. Ren, L. et al. A brief review of forensically important flesh flies (Diptera: Sarcophagidae). Forensic Sci. Res. 3, $16-26$ (2018).

29. Chakraborty, A., Ansar, W., Ghosh, S. \& Banerjee, D. The first report of the life cycle of Sarcophaga (L) dux on dead reptilian carcass: their application as forensic indicators. SAJB 2, 731-739 (2014).

30. Bugelli, V. et al. Forensic entomology and the estimation of the minimum time since death in indoor cases. J. Forensic Sci. 60, 525-531 (2015).

31. Meira, L. M. R., Barbosa, T. M., Jales, J. T., Santos, A. N. \& Gama, R. A. Insects associated to crime scenes in the northeast of brazil: consolidation of collaboration between entomologists and criminal investigation institutes. J. Med. Entomol. https://doi. org/10.1093/jme/tjaa040 (2020).

32. Magni, P. A., Pacini, T., Pazzi, M., Vincenti, M. \& Dadour, I. R. Development of a GC-MS method for methamphetamine detection in Calliphora vomitoria L. (Diptera: Calliphoridae). Forensic Sci. Int. 241, 96-101 (2014).

33. Grassberger, M. \& Reiter, C. Effect of temperature on development of Liopygia (= Sarcophaga ) argyrostoma (Robineau-Desvoidy) (Diptera: Sarcophagidae) and its forensic implications. J. Forensic Sci. 47, 1332-1336 (2002).

34. Szpila, K., Richet, R. \& Pape, T. Third instar larvae of flesh flies (Diptera: Sarcophagidae) of forensic importance-critical review of characters and key for European species. Parasitol. Res. 114, 2279-2289 (2015).

35. Niederegger, S., Szpila, K. \& Mall, G. Muscle attachment site (MAS) patterns for species determination in five species of Sarcophaga (Diptera: Sarcophagidae). Parasitol. Res. 115, 241-247 (2016).

36. Jordaens, K. et al. Identification of forensically important Sarcophaga species (Diptera: Sarcophagidae) using the mitochondrial COI gene. Int. J. Legal Med. 127, 491-504 (2013).

37. Municio, A. M. Lipid metabolism during devleopment in insects. in Function and Biosynthesis of Lipids. Advances in Experimental Medicine and Biology (eds. Bazán, N. G., Brenner, R. R. \& Giusto, N. M.) 83, 241-248 (Springer, New York, 1977).

38. Gołębiowski, M. et al. Developmental changes in the sterol composition and the glycerol content of cuticular and internal lipids of three species of flies. Chem. Biodivers. 10, 1521-1530 (2013).

39. Gołębiowski, M. et al. The composition of the cuticular and internal free fatty acids and alcohols from Lucilia sericata males and females. Lipids 47, 613-622 (2012).

40. Gołębiowski, M. et al. Free fatty acids in the cuticular and internal lipids of Calliphora vomitoria and their antimicrobial activity. J. Insect Physiol. 59, 416-429 (2013).

41. Gołębiowski, M., Maliński, E., Boguś, M. I., Kumirska, J. \& Stepnowski, P. The cuticular fatty acids of Calliphora vicina, Dendrolimus pini and Galleria mellonella larvae and their role in resistance to fungal infection. Insect Biochem. Mol. Biol. 38, 619-627 (2008).

42. Cerkowniak, M., Boguś, M. I., Włóka, E., Stepnowski, P. \& Gołębiowski, M. The composition of lipid profiles in different developmental stages of Dermestes ater and Dermestes maculatus and their susceptibility to the entomopathogenic fungus Conidiobolus coronatus. Phytoparasitica 48, 247-260 (2020).

43. Wrońska, A. K. et al. Cuticular fatty acids of Galleria mellonella (Lepidoptera) inhibit fungal enzymatic activities of pathogenic Conidiobolus coronatus. PLoS ONE 13, e1092715 (2018).

44. Kazek, M., Kaczmarek, A., Wrońska, A. K. \& Boguś, M. I. Diet influences the bacterial and free fatty acid profiles of the cuticle of Galleria mellonellalarvae. PLoS ONE 14, e0112567 (2019).

45. Horne, I., Haritos, V. S. \& Oakeshott, J. G. Comparative and functional genomics of lipases in holometabolous insects. Insect Biochem. Mol. Biol. 39, 547-567 (2009).

46. Stanley-Samuelson, D. W., Jurenka, R. A., Cripps, C., Blomquist, G. J. \& de Renobales, M. Fatty acids in insects: composition, metabolism, and biological significance. Arch. Insect Biochem. Physiol. 9, 1-33 (1988).

47. Soulages, J. L. \& Wells, M. A. Metabolic fate and turnover rate of hemolymph free fatty acids in adult Manduca sexta. Insect Biochem. Mol. Biol. 24, 79-86 (1994).

48. Lockey, K. H. Lipids of the insect cuticle: origin, composition and function. Comp. Biochem. Physiol. B. 89, 595-645 (1988).

49. Wigglesworth, V. B. Sclerotin and lipid in the waterproofing of the insect cuticle. Tissue Cell 17, 227-248 (1985).

50. Lockey, K. H. Insect cuticular lipids. Comp. Biochem. Physiol. B. 81, 263-273 (1985).

51. Blomquist, G. J., Nelson, D. R. \& De Renobales, M. Chemistry, biochemistry, and physiology of insect cuticular lipids. Arch. Insect Biochem. Physiol. 6, 227-265 (1987).

52. Braga, M. V., Pinto, Z. T., de Carvalho Queiroz, M. M., Matsumoto, N. \& Blomquist, G. J. Cuticular hydrocarbons as a tool for the identification of insect species: puparial cases from Sarcophagidae. Acta Trop. 128, 479-485 (2013).

53. Liepert, C. \& Dettner, K. Recognition of aphid parasitoids by honeydew-collecting ants: the role of cuticular lipids in a chemical mimicry system. J. Chem. Ecol. 19, 2143-2153 (1993)

54. Kerwin, J. L. Chemical control of the germination of asexual spores of Entomophthora culicis, a fungus parasitic on dipterans. J. Gen. Microbiol. 128, 2179-2186 (1982).

55. Urbanek, A. et al. Composition and antimicrobial activity of fatty acids detected in the hygroscopic secretion collected from the secretory setae of larvae of the biting midge Forcipomyia nigra (Diptera: Ceratopogonidae). J. Insect Physiol. 58, 1265-1276 (2012).

56. Jackson, L. L., Armold, M. T. \& Regnier, F. E. Cuticular lipids of adult fleshflies, Satcophaga bullata. Insect Biochem. 4, 369-379 (1974).

57. Qiu, Y. et al. An insect-specific P450 oxidative decarbonylase for cuticular hydrocarbon biosynthesis. Proc. Natl. Acad. Sci. USA 109, 14858-14863 (2012).

58. Sun, G. Y. \& Brookes, V. J. The deposition of lipid and the composition of neutral lipids in the fat body of Sarcophaga bullata (Diptera). Comp. Biochem. Physiol. 24, 177-185 (1968).

59. Thompson, S. N. A review and comparative characterization of the fatty acid compositions of seven insect orders. Comp. Biochem. Physiol. B Biochem. 45, 467-482 (1973).

60. Downer, R. G. H. Lipid metabolism. in Biochemistry (eds. Kerkut, G. A. \& Gilbert, L. I.) 77-113 (Pergamon, 1985). https://doi. org/10.1016/B978-0-08-030811-1.50009-X 
61. Starling, A. P., East, J. M. \& Lee, A. G. Effects of phosphatidylcholine fatty acyl chain length on calcium binding and other functions of the (Ca2+-Mg2+)-ATPase. Biochemistry 32, 1593-1600 (1993).

62. Bennett, V. A., Pruitt, N. L. \& Lee, R. E. Seasonal changes in fatty acid composition associated with cold-hardening in third instar larvae of Eurosta solidaginis. J. Comp. Physiol. B Biochem. Syst. Environ. Physiol. 167, 249-255 (1997).

63. Bashan, M. \& Cakmak, O. Changes in composition of phospholipid and triacylglycerol fatty acids prepared from prediapausing and diapausing individuals of Dolycoris baccarum and Piezodorus lituratus (Heteroptera: Pentatomidae). Ann. Entomol. Soc. Am. 98, 575-579 (2006).

64. Goto, S. G. \& Katagiri, C. Effects of acclimation temperature on membrane phospholipids in the flesh fly Sarcophaga similis. Entomol. Sci. 14, 224-229 (2011).

65. Michaud, M. R. \& Denlinger, D. L. Oleic acid is elevated in cell membranes during rapid cold-hardening and pupal diapause in the flesh fly, Sarcophaga crassipalpis. J. Insect Physiol. 52, 1073-1082 (2006).

66. Howard, R. W. \& Stanley-Samuelson, D. W. Fatty acid composition of fat body and Malpighian tubules of the tenebrionid beetle, Zophobas atratus: significance in eicosanoid-mediated physiology. Comp. Biochem. Physiol. B Biochem. Mol. Biol. 115, 429-437 (1996).

67. Stanley-Samuelson, D. W. \& Loher, W. Prostaglandins in insect reproduction. Ann. Entomol. Soc. Am. 79, 841-853 (1986).

68. Pärnänen, S. \& Turunen, S. Eicosapentaenoic acid in tissue lipids of Pieris brassicae. Experientia 43, 215-217 (1987).

69. Bell, J. G. \& Sargent, J. R. Arachidonic acid in aquaculture feeds: current status and future opportunities. Aquaculture 218, 491-499 (2003).

70. Van Anholt, R. D., Koven, W. M., Lutzky, S. \& Wendelaar Bonga, S. E. Dietary supplementation with arachidonic acid alters the stress response of gilthead seabream (Sparus aurata) larvae. Aquaculture 238, 369-383 (2004).

71. Lord, J. C., Anderson, S. \& Stanley, D. W. Eicosanoids mediate Manduca sexta cellular response to the fungal pathogen Beauveria bassiana: a role for the lipoxygenase pathway. Arch. Insect Biochem. Physiol. 51, 46-54 (2002).

72. Stanley, D. \& Kim, Y. Eicosanoid signaling in insects: from discovery to plant protection. CRC. Crit. Rev. Plant Sci. 33, 20-63 (2014).

73. Shrestha, S. \& Kim, Y. Various eicosanoids modulate the cellular and humoral immune responses of the beet armyworm, Spodoptera exigua. Biosci. Biotechnol. Biochem. 73, 2077-2084 (2009).

74. Yajima, M. et al. A newly established in vitro culture using transgenic Drosophila reveals functional coupling between the phospholipase A2-generated fatty acid cascade and lipopolysaccharide-dependent activation of the immune deficiency (IMD) pathway in insect immunity. Biochem. J. 371, 205-210 (2003).

75. Clements, J., Olson, J. M., Sanchez-Sedillo, B., Bradford, B. \& Groves, R. L. Changes in emergence phenology, fatty acid composition, and xenobiotic-metabolizing enzyme expression is associated with increased insecticide resistance in the Colorado potato beetle. Arch. Insect Biochem. Physiol. 103, 3 (2020).

76. Gołębiowski, M. et al. Antimicrobial activity of untypical lipid compounds in the cuticular and internal lipids of four fly species. J. Appl. Microbiol. 116, 269-287 (2014).

77. Ortiz-Urquiza, A. et al. Insect Physiology and Biochemistry Insect Physiology and Biochemistry 56th edn. (CRC Press, Boca Raton, 2015).

78. Gutierrez, A. C. et al. Cuticle fatty acid composition and differential susceptibility of three species of cockroaches to the entomopathogenic fungi Metarhizium anisopliae (Ascomycota, Hypocreales). J. Econ. Entomol. 108, 752-760 (2015).

79. Kaczmarek, A. et al. The interaction between cuticle free fatty acids (FFAs) of the cockroaches Blattella germanica and Blatta orientalis and hydrolases produced by the entomopathogenic fungus Conidiobolus coronatus. PLoS ONE 15, e0235785 (2020).

80. Smith, R. J. \& Grula, E. A. Toxic components on the larval surface of the corn earworm (Heliothis zea) and their effects on germination and growth of Beauveria bassiana. J. Invertebr. Pathol. 39, 15-22 (1982).

81. Boguś, M. I. et al. Effects of insect cuticular fatty acids on in vitro growth and pathogenicity of the entomopathogenic fungus Conidiobolus coronatus. Exp. Parasitol. 125, 400-408 (2010).

82. Boguś, M. I. et al. Cuticle hydrolysis in four medically important fly species by enzymes of the entomopathogenic fungus Conidiobolus coronatus. Med. Vet. Entomol. 31, 23-35 (2017).

83. Capinera, J. L. Encyclopedia of entomology Choice Reviews Online 42 (Springer, Dordrecht, 2005)

84. Downer, R. G. H. \& Matthews, J. R. Patterns of lipid distribution and utilisation in insects. Integr. Comp. Biol. 16, 733-745 (1976).

85. Pickett, K. M., McHenry, A. \& Wenzel, J. W. Nestmate recognition in the absence of a pheromone. Insectes Soc. 47, 212-219 (2000).

86. Gołebiowski, M., Boguś, M. I., Paszkiewicz, M. \& Stepnowski, P. The composition of the free fatty acids from Dendrolimus pini exuviae. J. Insect Physiol. 56, 391-397 (2010).

87. Youn, K. et al. Fatty acid and volatile oil compositions of Allomyrina dichotoma larvae. Prev. Nutr. Food Sci. 17, 310-314 (2012).

88. Yeo, H. et al. Fatty acid composition and volatile constituents of Protaetia brevitarsis larvae. Prev. Nutr. Food Sci. 18, 150-156 (2013).

89. Ghosh, S., Lee, S. M., Jung, C. \& Meyer-Rochow, V. B. Nutritional composition of five commercial edible insects in South Korea. J. Asia. Pac. Entomol. 20, 686-694 (2017).

90. Akinnawo, O. \& Ketiku, A. O. Chemical composition and fatty acid profile of edible larva of Cirina Forda (Westwood). African J. Biomed. Res. 3, 93-96 (2000).

91. Truman, J. W. \& Riddiford, L. M. The evolution of insect metamorphosis: A developmental and endocrine view. Philos. Trans. R. Soc. B. 374, 20190070 (2019).

92. Bodenstein, D. The postembryonic development of Drosophila. in Biology of Drosophila (ed. Demerec, M.) 275-367 (Wiley, Hoboken, 1950).

93. Kawaguchi, N., Komano, H. \& Natori, S. Involvement of Sacrophaga lectin in the development of imaginal discs of Sarcophaga peregrina in an autocrine manner. Dev. Biol. 144, 86-93 (1991).

94. Kurata, S., Komano, H. \& Natori, S. Dissociation of Sarcophaga peregrina (flesh fly) fat body by pupal haemocytes in vitro. J. Insect Physiol. 35, 559-565 (1989).

95. Khan, R., Khanam, Z. \& Khan, A. U. Isolation and characterization of n-octacosanoic acid from Viburnum foetens: a novel antibiofilm agent against Streptococcus mutans. Med. Chem. Res. 21, 1411-1417 (2012).

96. Blomquist, G. J., Chu, A. J. \& Remaley, S. Biosynthesis of wax in the honeybee, Apis mellifera L. Insect Biochem. 10, 313-321 (1980).

97. Gołębiowski, M. Comparison of free fatty acids composition of cuticular lipids of Calliphora vicina larvae and pupae. Lipids 47, 1001-1009 (2012).

98. Hurst, H. An electron diffraction study of the crystalline structure of the lipids in the pupal excuviae of Calliphora erythrocephala. J. Exp. Biol. 27, 238-252 (1950).

99. Wessels, F. J., Jordan, D. C. \& Hahn, D. A. Allocation from capital and income sources to reproduction shift from first to second clutch in the flesh fly, Sarcophaga srassipalpis. J. Insect Physiol. 56, 1269-1274 (2010).

100. Brown, D. A. Lipid droplets: proteins floating on a pool of fat. Curr. Biol. 11, R446-R449 (2001).

101. Martin, S. \& Parton, R. G. Lipid droplets: a unified view of a dynamic organelle. Nat. Rev. Mol. Cell Biol. 7, 373-378 (2006).

102. Grönke, S. et al. Dual lipolytic control of body fat storage and mobilization in Drosophila. PLoS Biol. 5, 1248-1256 (2007). 
103. Oraha, V. S. \& Lockey, K. H. Cuticular lipids of Locusta migratoria migratoriodes (R and F), Schistocerca gregaria (Forskål) (Acrididae) and other orthopteran species - I. Polar components. Comp. Biochem. Physiol. B 95, 603-608 (1990).

104. Dadd, R. H. Essential fatty acids for the mosquito Culex pipiens. J. Nutr. 110, 1152-1160 (1980).

105. Dadd, R. H., Kleinjan, J. E. \& Stanley-Samuelson, D. W. Polyunsaturated fatty acids of mosquitos reared with single dietary polyunsaturates. Insect Biochem. 17, 7-16 (1987).

106. Canavoso, L. E., Jouni, Z. E., Karnas, K. J., Pennington, J. E. \& Wells, M. A. Fat metabolism in insects. Annu. Rev. Nutr. 21, 23-46 (2001).

107. Jurenka, R. Insect Pheromone Biosynthesis. in The Chemistry of Pheromones and Other Semiochemicals I (ed. Schulz, S.) 97-132 (Springer, New York, 2004). https://doi.org/10.1007/b95450

108. Potter, C. F. \& Bertin, R. I. Amino acids in artificial nectar: feeding preferences of the flesh fly Sarcophaga bullata. Am. Midl. Nat. 120, 156 (1988).

109. Rathman, E. S., Lanza, J. \& Wilson, J. Feeding preferences of flesh flies (Sarcophaga bullata) for sugar-only vs. sugar-amino acid nectars. Am. Midl. Nat. 124, 379 (1990).

110. Bänziger, H. \& Pape, T. Flowers, faeces and cadavers: Natural feeding and laying habits of flesh flies in Thailand (Diptera: Sarcophagidae, Sarcophaga spp.). J. Nat. Hist. 38, 1677-1694 (2004).

111. Wood, J. D., Enser, M., Richardson, R. I. \& Whittington, F. M. Fatty acids in meat and meat products. in Fatty Acids in Foods and their Health Implications, Third Edition 87-107 (2007).

112. Daley, C. A., Abbott, A., Doyle, P. S., Nader, G. A. \& Larson, S. A review of fatty acid profiles and antioxidant content in grass-fed and grain-fed beef. Nutr. J. 9, 1 (2010).

113. Wood, J. D. et al. Effects of fatty acids on meat quality: a review. Meat Sci. 66, 21-32 (2004).

114. Arrese, E. L. \& Soulages, J. L. Insect fat body: energy, metabolism, and regulation. Annu. Rev. Entomol. 55, 207-225 (2010).

115. Capps, K. et al. Diet dependent cycling of protease activity in the midgut of the fleshfly, Sarcophaga bullata. Isr. J. Entomol. 7, 99-108 (1972).

116. Stanley-Samuelson, D. W. \& Dadd, R. H. Arachidonic and other tissue fatty acids of Culex pipiens reared with various concentrations of dietary arachidonic acid. J. Insect Physiol. 27, 571-578 (1981)

117. Stanley-Samuelson, D. W. \& Dadd, R. H. Polyunsaturated fatty acids in the lipids from adult Galleria mellonella reared on diets to which only one unsaturated fatty acid had been added. Insect Biochem. 14, 321-327 (1984).

118. Gadelhak, G. G., Pedibhotla, V. K., Rosario, R. M. T., Thomas, G. D. \& Stanley-Samuelson, D. W. The influence of blood meals on accumulation of arachidonic acid by adult stable flies. Comp. Biochem. Physiol. B Biochem. 110, 613-621 (1995).

119. Durmuş, Y. et al. Eicosanoids mediate melanotic nodulation reactions to viral infection in larvae of the parasitic wasp, Pimpla turionellae. J. Insect Physiol. 54, 17-24 (2008).

120. Uryu, O., Ameku, T. \& Niwa, R. Recent progress in understanding the role of ecdysteroids in adult insects: Germline development and circadian clock in the fruit fly Drosophila melanogaster. Zool. Lett. 1, 1 (2015).

121. Clayton, R. B. The utilization of sterols by insects. J. Lipid Res. 15, 3-19 (1964).

122. Svoboda, J. A., Kaplanis, J. N., Robbins, W. E. \& Thompson, M. J. Recent developments in insect steroid metabolism. Annu. Rev. Entomol. 20, 205-220 (1975).

123. Bosch, O. J., Geier, M. \& Boeckh, J. Contribution of fatty acids to olfactory host finding of female Aedes aegypti. Chem. Senses 25, 323-330 (2000).

124. Smallegange, R. C., Qiu, Y. T., Bukovinszkiné-Kiss, G., Van Loon, J. J. A. \& Takken, W. The effect of aliphatic carboxylic acids on olfaction-based host-seeking of the malaria mosquito Anopheles gambiae sensu stricto. J. Chem. Ecol. 35, 933-943 (2009).

125. Barrozo, R. B. \& Lazzari, C. R. Orientation behaviour of the blood-sucking bug Triatoma infestans to short-chain fatty acids: synergistic effect of L-lactic acid and carbon dioxide. Chem. Senses 29, 833-841 (2004).

126. Mullens, B. A., Reifenrath, W. G. \& Butler, S. M. Laboratory trials of fatty acids as repellents or antifeedants against houseflies, horn flies and stable flies (Diptera: Muscidae). Pest Manag. Sci. 65, 1360-1366 (2009).

127. Skinner, W. A., Tong, H. C., Maibach, H. I. \& Skidmore, D. Human skin-surface lipid fatty acids: mosquito repellents. Experientia 26, 728-730 (1970).

128. Fougeron, A. S., Farine, J. P., Flaven-Pouchon, J., Everaerts, C. \& Ferveur, J. F. Fatty-acid preference changes during development in Drosophila melanogaster. PLoS ONE 6, e26899 (2011).

129. Blaul, B. et al. Oleic acid is a precursor of linoleic acid and the male sex pheromone in Nasonia vitripennis. Insect Biochem. Mol. Biol. 51, 33-40 (2014).

130. Sereno, A. P., Salvo, A. \& Battán-Horenstein, M. Trophic interactions between parasitoids and necrophagous flies in Central Argentina. Acta Trop. 162, 229-232 (2016).

131. Pennacchio, F. \& Strand, M. R. Evolution of developmental strategies in parasitic Hymenoptera. Annu. Rev. Entomol. 51, 233-258 (2006).

132. Mair, M. M. \& Ruther, J. Chemical ecology of the parasitoid wasp genus Nasonia (Hymenoptera, Pteromalidae). Front. Ecol. Evol. 7, 1-10 (2019).

133. Rivers, D. B., Hink, W. F. \& Denlinger, D. L. Toxicity of the venom from Nasonia vitripennis (Hymenoptera : Pteromalidae) toward fly hosts, nontarget insects, different developmental stages, and cultured insect cells. Toxicon 31, 755-765 (1993).

134. Rivers, D. B. \& Denlinger, D. L. Venom-induced alterations in fly lipid metabolism and its impact on larval development of the ectoparasitoid Nasonia vitripennis (Walker) (Hymenoptera: Pteromalidae). J. Invertebr. Pathol. 66, 104-110 (1995).

135. Bhadra, P., Hart, A. J. \& Hall, M. J. R. Factors affecting accessibility to blowflies of bodies disposed in suitcases. Forensic Sci. Int. 239, 62-72 (2014).

136. Visser, B. et al. Transcriptional changes associated with lack of lipid synthesis in parasitoids. Genome Biol. Evol. 4, 752-762 (2012).

137. Visser, B. et al. Loss of lipid synthesis as an evolutionary consequence of a parasitic lifestyle. Proc. Natl. Acad. Sci. USA 107, $8677-8682(2010)$.

138. Thompson, S. N. \& Barlow, J. S. The Fatty acid composition of parasitic Hymenoptera and its possible biological significance. Ann. Entomol. Soc. Am. 67, 627-632 (1974).

139. Martinson, E. O. et al. Nasonia vitripennis venom causes targeted gene expression changes in its fly host. Mol. Ecol. 23, 5918-5930 (2014).

140. Danneels, E. L. et al. Early changes in the pupal transcriptome of the flesh fly Sarcophagha crassipalpis to parasitization by the ectoparasitic wasp, Nasonia vitripennis. Insect Biochem. Mol. Biol. 43, 1189-1200 (2013).

141. Rivers, D. B., Rocco, M. M. \& Frayha, A. R. Venom from the ectoparasitic wasp Nasonia vitripennis increases Na+ influx and activates phospholipase $\mathrm{C}$ and phospholipase $\mathrm{A} 2$ dependent signal transduction pathways in cultured insect cells. Toxicon 40, 9-21 (2002).

142. Rivers, D. B. \& Denlinger, D. L. Redirection of metabolism in the flesh fly, Sarcophaga bullata, following envenomation by the ectoparasitoid Nasonia vitripennis and correlation of metabolic effects with the diapause status of the host. J. Insect Physiol. 40, 207-215 (1994).

143. Nakamatsu, Y. \& Tanaka, T. Venom of Euplectrus separatae causes hyperlipidemia by lysis of host fat body cells. J. Insect Physiol. 50, 267-275 (2004). 
144. Cerkowniak, M., Puckowski, A., Stepnowski, P. \& Gołebiowski, M. The use of chromatographic techniques for the separation and the identification of insect lipids. J. Chromatogr. B 937, 67-78 (2013).

\section{Acknowledgements}

We are grateful to Lena Siecińska, Anna Krawiel and Ewelina Mokijewska for their technical support. We would like to thank prof Krzysztof Szpila for his help with species identification.

\section{Author contributions}

Each author have approved the submitted version (and any substantially modified version that involves the author's contribution to the study) and have agreed both to be personally accountable for the author's own contributions and to ensure that questions related to the accuracy or integrity of any part of the work, even ones in which the author was not personally involved, are appropriately investigated, resolved, and the resolution documented in the literature. A.K.-conception, design of the work, analysis, interpretation of data, writingoriginal draft. A.K.W.—design of the work. M.K.—conception. M.I.B.—conception, supervision, writing-review \& editing.

\section{Funding}

This work was partly supported by two grants: National Centre for Research and Development Grant POIG.01.04.00-14-019/12 and Masovian district Grant RPMA.01.02.00-14-5626/16-00 to the Biomibo company.

\section{Competing interests}

The authors have read the journal's policy and have the following conflicts: MIB is the President of Biombio and Biomibo company purchase chemicals, and made laboratory equipment available for AK, AKW and MK. The specific roles of these authors are articulated in the 'author contributions' section. The funders did not have any additional role in the study design, data collection and analysis, decision to publish, or preparation of the manuscript. There are no patents, products in development or market products to declare.

\section{Additional information}

Supplementary information is available for this paper at https://doi.org/10.1038/s41598-020-74475-1.

Correspondence and requests for materials should be addressed to A.K.

Reprints and permissions information is available at www.nature.com/reprints.

Publisher's note Springer Nature remains neutral with regard to jurisdictional claims in published maps and institutional affiliations.

(c) (i) Open Access This article is licensed under a Creative Commons Attribution 4.0 International License, which permits use, sharing, adaptation, distribution and reproduction in any medium or format, as long as you give appropriate credit to the original author(s) and the source, provide a link to the Creative Commons licence, and indicate if changes were made. The images or other third party material in this article are included in the article's Creative Commons licence, unless indicated otherwise in a credit line to the material. If material is not included in the article's Creative Commons licence and your intended use is not permitted by statutory regulation or exceeds the permitted use, you will need to obtain permission directly from the copyright holder. To view a copy of this licence, visit http://creativecommons.org/licenses/by/4.0/.

(C) The Author(s) 2020 